\title{
Rozmowy na Polach Elizejskich królów polskich
}

Jacek Wójcicki 


\section{JACEK WÓJCICKI}

\section{Rozmowy na Polach Elizejskich królów polskich}

Publikowane niżej dwa dialogi pochodzą z okresu konfederacji barskiej (ściśle jej schyłku). Odzwierciedlają one punkt widzenia działającego wówczas stronnictwa saskiego z jego koronną koncepcją odsunięcia na zawsze „Piastów” od tronu. Nawiązują do wielce popularnego w Oświeceniu gatunku dialogów zmarłych, znanego zwłaszcza z bliskich czasowo wzorców niemieckich. Liczne podobieństwa stylu i frazeologii świadczą o wspólnym dla obu utworów autorstwie, chociaż dzieli je blisko rok. Rozmowa... Augusta III i Stanisława Leszczyńskiego powstała prawdopodobnie bezpośrednio po detronizacji Stanisława Augusta 13 października 1770 roku, a więc na jesieni lub zimą tego roku. Rozmowa druga... zaś włącza się v/ nurt publicystyki wywołanej zamachem na króla z 3 listopada 1771 roku. Kilka pochwalnych zdań obu dialogom poświęcił Władysław Konopczyński (Konfederacja barska, t. 2, Warszawa 1938, s. 569-570), znalazły też swoje miejsce w monografii gatunku (Zofia Sinko, Oświeceni wśród Pól Elizejskich. Rozmowy zmarłych - recepcja - twórczość oryginalna, Wrocław 1976, s. 174-178). Badacze podkreślają ich niezłą jakość literacką i sprawny, czysty język (interesujące, że najwięcej wtrętów łacińskich pojawia się w cytowanych dokumentach - rzekomo - konfederacji!)

Tekstem podstawowym niniejszej edycji jest wykorzystany przez Z. Sinkową odpis z biblioteki Branickich w Suchej (obecnie AGAD, sygn. Sucha 248/300) - niewielkiego formatu tomik, zawierający ponad dziesięć dialogów i pism polemicznych z przełomu lat sześćdziesiątych i siedemdziesiątych. Tekst pierwszej Rozmowy (pozbawionej w tytule, podobnie jak druga, daty) porównano $z$ następującymi kopiami:

1. Oss. 330 II k. 58-66 v. (w tytule błędnie data 1771; odpis wzmiankowany przez Konopczyńskiego),

2. BOZ 964 t.1, s.1016-1032 (odpis niekompletny, w tytule data 1770),

3. AGAD ApP 73 t.1, s.678-700 (oba powyższe wspomniane przez Z. Sinkową).

Wymieniony przez Konopczyńskiego odpis z Biblioteki Ordynacji Krasińskich nie przetrwał II wojny światowej.

Rozmowę drugą zapisano w rpsie z Suchej na s.125-187. Porównano ją z odpisem AGAD ApP 73 t.1, s. 701-713. Tekst znajduje się również w sylwie Strawińskich ze zbiorów BUW, rps 274 , t.4, s. 1721-1737, lecz jest to odpis bardzo zniszczony i nie mógł służyć do porównań. Ze względu na niewielką bazę źródłową przypisy do obu dialogów starają się dość dokładnie zorientować czytelnika nie tylko w brzmieniu poprawnym tekstu, lecz i licznych nieścisłościach i wahaniach odpisów, nieraz błędnych, niemniej istotnych dla obrazu wędrówek tekstu. 
ROZMOWA NA POLACH ELIZEJSKICH KRÓLÓW POLSKICH AUGUSTA III I STANISŁAWA LESZCZYŃSKIEGO

Rps AGAD Sucha 248/300 s.82-124

\section{August}

Żądany i troskliwie czekany gościu, gdy cię witam, czuję nieporównaną na sercu moim pociechę $z$ widzenia tak zacnego i nad szczęście, nad przypadki większego bohatyra.

\section{Stanisław}

Winszuję i ja sobie tego szczęścia, że w tym okręgu wieczności mogę poufale $z$ tym monarchą według żądania serca pomówić, którego na tamtym świecie żyjąc kochać nie mogłem, choć godnego kochania sądziłem.

\section{August}

Taka jest dola, taki jest stan śmiertelnych ludzi doczesny bieg życia pędzących, że lubo serce ich czasem jest $w$ gruncie samym dobre, przecież udawać się musi dla interesu, dla stałości w sentymentach poczętych nieludzkim i okrutnym.

\section{Stanisław}

Auguście, widzę dopiero, że to, co ci przyznawał świat, jest szczerą prawdą. Mówiono zawsze o tobie, żeś dla ludzkości przyjemnej, dla wspaniałej i godnej dusz wielkich wspaniałości był dobrym królem, kiedy i teraz dajesz tego dowody, wymawiając i zasłaniając moję winę ku tobie i ojcu twemu popełnioną.

\section{August}

Ja nie znałem w istocie samej żadnej twojej winy przeciwko szczęściu mojemu. Czyniłeś to, coś czynić był powinien, szedłeś za losem i predestynacyją ; zwabił cię wolny naród i przynaglał do korony, jakże się było nie powierzyć tak możnemu i dobrze kierującemu się okrętowi??

\section{Stanisław}

Ale ojciec twój ( $z$ którym także mówić pragnę) musi być dotąd urażony, lubo za życia swego mądrze żal swój dysymulował, bo przeciwko niemu cale niesprawiedliwy krok mój był i podstęp poczciwego ${ }^{3}$ człeka wcale niegodny.

\section{August}

Więc miał dość na tym, żeś się sam nazwał uzurpatorem gwałtownym i spokojność panowania jego niesłusznie mieszającym. Już się to skończyło wszystko;

\footnotetext{
'Predestynacyja - Oss. 330: przeznaczeniem.

${ }^{2}$ Jakże się było nie powierzyć... - Oss. 330: jakże się było tak jednostajnemu jego kochaniu i chęciom opierać?

${ }^{3}$ Poczciwego - Oss. 330, BOZ 964: cnotliwego.
} 
szczęśliwszyś ty, że mając imię króla polskiego nie miałeś kłopotu i pozbyłeś się wzgardy oczywistej, na którą się koniecznie poświęcić powinien, kto chce w PoIszcze królować, zwłaszcza w tych czasach, gdzie wolność poszła w swywolą, na której skutki krajowi fatalne i jawną obelgą ku majestatowi okazujące przez szpary patrzeć potrzeba.

\section{Stanisław}

Prawda, że dostatecznie wyrazić niepodobna cierpliwości i dobroci twojej na te zwłaszcza przez ostatnim wyjazdem twoim afronty od familiji Czartoryskich, których ojciec twój wyniósł i ludźmi poczynił znacznymi.

\section{August}

Ojciec mój prawdziwie kochał to królestwo, przeto obywatelów jego nigdy groźbą ani gniewem, ani zemstą dobrymi czynić nie chciał.

\section{Stanisław}

Tak mówiono o nim, ale nie wszyscy i nie wszędzie.

\section{August}

Jeszcze o żadnym ‘najlepszym ${ }^{4}$ monarsze wszędzie i wszyscy, zwłaszcza za życia, nie zgodzili się. Dość sławy, że lepsi i znaczniejsi przyznają komu chwałę cnoty.

\section{Stanisław}

W Polszcze jest po królu najznakomitszy prymas, a ten tak nie trzymał o nim.

\section{August}

O Radziejowskim wspominasz, który i tobie zapewnie nie sprzyjał, chociaż niby $z$ twoim bohatyrem Karolem złączył się i spiknął na detronizacyją mego ojca? Lecz ten, chociaż był najznakomitszy powagą urzędu i dostojeństwa, był jednak w całej Polszcze ‘człowiek` najniegodziwszy ${ }^{5}$, nie kochający Boga ani Kościoła ${ }^{6}$, ani króla, ani bliźniego...

\section{Stanisław}

Jak to nie? alboż nie kochał Towiańskiej, z której ${ }^{7}$ syna spłodzonego chciał królem polskim uczynić? Przecież mu mazowieckie województwo z nią wymalowanemu ${ }^{8}$ kazało przypisać z księgi pieni Salomonowych: Dilectus meus mihi et ego illi.

\footnotetext{
${ }^{4}$ Najlepszym - brak w rpsie, uzup. za Oss. 330 i BOZ 964.

${ }^{5}$ Człowiek - brak w rpsie; uzup. jw.; najniegodziwszy - BOZ 964: najniepoczciwszy.

${ }^{5}$ Boga - Oss. 330, BOZ 964: Boga ani ojczyzny; Kościoła - brak w BOZ 964.

${ }^{7}$ Z której - Oss. 330, BOZ 964: z którą.

${ }^{8}$ Wymalowanemu - ApP 73: wychowanemu.
} 


\section{August}

Żartujesz swoim zwyczajem. Taką rzeczą i dzisiejszy w Polszcze prymas, jak słyszałem ${ }^{9}$, wart pochwały z swojego ku Emkini przywiązania.

\section{Stanisław}

To rzecz pewna, że gdyby za panowania mojego prymas takim był szachrem, tak niecnotliwym i dyfidencyją niegodziwie czyniącym inter maiestatem et libertatem, pewnie bym go dał na przykład duchowieństwu cad Angeli arcem, ${ }^{10}$. Jakoż moja myśl była rugować biskupów z senatu, opisać prymasów i wolność zregulować nadto wybiegłą z obrębów w Polszcze, i dałem już to w moich myślach, które z druku wyszły, to w manuskrypcie Głos publiczny wolnego obywatela do tego projekt; musiałaby mi Polska być inszą niedługo.

\section{August}

Dlatego też nie wierzył ci naród i zaraz w początkach twoimi przerażony plantami zląkł się ciebie, aby z równego niegdyś innym obywatela nie doznał cię Pizystrata, tyrana, religij i wolności opresora, praw i swobód narodowych wzgardziciela, tak jako o twoim imienniku dziesiejszym polskim słychać, któregoś ty pokochał i któremu aż do podłości wyrażenia na starość nieprzyzwoitej winszowałeś tronu i przydałeś to: „Czego stary Stanisław nie mógł dokonać, choć szczerze chciał, d'a Rzeczypospolitej, aby ${ }^{11}$ młody Stanisław poprawił".

\section{Stanisław}

To tu, widzę, wszystko wam jest wiadomo; i ci tu w tym nieśmiertelnym kraju, widzę, są rozumni, którzy się na świecie tamtym między nami jak nieme bałwany zdawali ${ }^{12}$.

\section{August}

Tak o mnie sądzono, tak pokątnie gadano, że ja niemy bałwan, iż w spokojności panowałem i myśli nawet nie miałem nigdy szkodzić wolności religij katolickiej panującej, chociaż mię sami Polacy, a co większa duchowni, do tego namawiali.

\section{Stanisław}

Możnali temu wierzyć? Polacy? Duchowni?

\section{August}

Weźmij, przeczytaj te punkta podane mi od... nie chcę powiedzieć od których Polaków, ani mię przymuszaj do tego, bo to jest przeciwko charakterowi memu i naturze. Bogu dziękuję, że mi nie dał serca obłudnego, zemsty pełnego, rozkosz

${ }^{9}$ Jak słyszałem - Oss. 330, BOZ 964: jak słyszemy.

${ }_{10}$ Dał - ApP 73: odesłał; ad Angeli arcem - brak w rpsie oraz Oss. 330 i BOZ 964; uzup. za ApP 73.

"Aby - brak w BOZ 964.

${ }^{12}$ Augusta III nazywano mutum simulacrum. [Przypis w rpsie podst.] 
mającego w zgubie poddaństwa i płaczu ich, które dzisiejszych monarchów są właściwe przymioty.

\section{Stanisław (czyta)}

„Miłościwy królu, daje ci te rady ten, który ci życzy dobrze, który cię królem wielkim chce widzieć w Polszcze i dziedzicem tronu mogącego stać się najznakomitszym w Europie. Primo: Nie dozwalaj stanom kombinacyi, znieś amnestyją, sejm pacificationis jako dający pochop do nierządu i zabójstwa skasuj prawem nowym. Partyzantów Stanisława wypędź za granicę, ukarz, obedrzyj ze wszystkiego, pod pozorem dalszej spokojności zabierz się potym do porządków; zrazu władnąć powoli zacznij wszystkim, starostwa skasuj albo na połowę podziel się z nich proweniencyją, podgarnij pod siebie mennicę, wojsko, stań się Augustem. Dobrze jest in turbido piscari. Udało się to Augustowi w Rzymie i jeszcze go kochano, w ręce całowano, spokojnym, miłym, dobrym monarchą, ojcem ojczyzny zwano - czemuż nie tobie Augustowi, z kochanego w narodzie ojca potomkowi najżądańszemu, do panowania jedynowładnego urodzonemu? Wszakże on własnymi obywatelów siłami mocniejszych wygubił, wolność ogarnął i z Rzeczypospolitej sławne uczynił dziedzictwo..."

\section{August (przerywa)}

To jedna rada. Ach! mógłżem taką niewdzięcznością narodowi zapłacić za jego miłość i potulność? mógłżem się na taki grzech odważyć ${ }^{13}$ nie zdobiący serca monarchy, serca poczciwego i Boga bojącego się?

Stanisław (czyta dalej)

"Secundo: Skleić się potrzeba z Rosyją, wszakże Piotr Aleksiejewicz służył dobrze ojcu Waszej Królewskiej Mości i kochał go szczerze..."

August (przerywa)

Kochał go po moskiewsku, oni tak kochają, że potrzeba po ich miłości płakać, jak teraz słychać o kochanej Polszcze.

\section{Stanisław}

Cóż się dzieje? Jakżeś się z niemego stał teraz gadatliwym! Nie przeszkadzaj czytaniu.

\section{August}

Teraz po śmierci wolno mi filozofować, politykować, za życia na tamtym świecie nie śmiałem i nie chciałem przez gruntowną serca mego dobroć narazić się nikomu.

\section{Stanisław}

Ale proszę, zastanów się! (czyta dalej) „Tertio: Gwarancyją rosyjską przyjąć, spróbowawszy wprzód dysydentów sił, poradziwszy onym, aby się porwali na ka-

\footnotetext{
${ }^{13}$ Mógłżem się na taki grzech odważyć... - BOZ 964: mogłem taką niewdzięczność popełnić...
} 
tolików, i Sasów, Prusaków sobie przysposobili, uprosili (o czym z królem pruskim trzeba się umówić, aby się on miał permissive i toż samo pobłażanie Sasom uczynić). Polacy naturalnie wiary aż do zabobonów i podległości ${ }^{14}$ ku Rzymowi trzymamy się. Porwiemy się zaraz na dysydentów rozruch w ojczyźnie czyniących, Wasza Królewska Mość trzymać się będziesz w obojętności, bardziej jednak z nakłonieniem życzliwości ku dysydentom. Zburzemy ${ }^{15}$ potym obywatelów gorliwych głupie za wiarę, na Waszą Królewską Mość w konfederacyją uderzemy. Będziemy niszczyć kraj, dwory, duchowne dobra i klasztory najeżdżać pod pretekstem wiary. Wojska będą już w mocy Waszej Królewskiej Mości, bo ante omnia, jakom rzekł, trzeba je podgarnąć pod siebie, komisyją z faworytów uczynić, hetmanów z senatorów na szlachtę obrócić albo zrobić ich ministrami, ale bez władzy w wojsku, przydać onym komisarzów ${ }^{16}$ i dyrektorów. Będą nas, konfederatów, ścigać wojska i zawsze bić naturalnie, bo egzercytowane, i trzeba by je zawczasu dysydentami napełnić. Uczynić tylko brata mego prezydentem komisyi wojskowej na dwa roki, to on katolików wytruje ${ }^{17}$, bo lubo on niby katolik i kapucynów kocha, ale diabelnie nie lubi Rzymu i moralności, nie może cierpieć katolika ‘rzemieślnika albo żołnierza ${ }^{18}$. Tak tedy nasi szlachta po sukurs do Moskwy, po gwarancyją co żywo ubiegać się będą, ale trafią z deszczu pod rynnę ${ }^{19}$. Odrwią się i zgubią sami swoim przemysłem; czym zdawać się im będzie, że zaszkodzą Waszej Królewskiej Mości, tym mu pomogą do uczynienia absolutności i dziedzictwa w Polszcze. Z Moskwą dopiero pogodzisz się Wasza Królewska Mość za interpozycjami cesarza, króla francuskiego i hiszpańskiego, a dysydentów opiszesz pewnymi raz na zawsze prawami, coś im wolności pozwoliwszy, i powoli jako August Rzymianów słodkością pokoju ich ujmiesz i śpiących wprowadzisz do jednostajnego posłuszeństwa, że zapomną o swoim ‘wszechmocnym²0 veto..."

\section{August (przerywa)}

Jaż to mogłem uczynić, który się brzydziłem bardziej nad szatana i piekło cygaństwem i matactwem, który nie mógłbym spojrzeć na człowieka, krzywdę mu uczyniwszy z umysłu i złości?

\section{Stanisław}

Co ja, nie ręczę za sobą, podobno bym był uczynił, chociażem nie miał tyle nadziei do utrzymania się przy moich projektach, ileś ty miał w swojej nierównie trwalszej mocy, którą by aaprehendować ${ }^{21}$ musieli. Przyznać ci trzeba, Auguście, żeś był w życiu nadto święty i powinien by cię Rzym sprawiedliwiej kanonizować

${ }^{14}$ Podległości - BOZ 964: podłości.

${ }_{15}$ Zburzemy - Oss. 330: zbierzemy.

${ }^{16}$ Komisarzów - Oss. 330: kosów; BOZ 964: kasów.

${ }_{17}$ Wytruje - Oss. 330: wypleni; BOZ 964: wytnie.

${ }^{18}$ Rzemieślnika albo żołnierza - brak w rpsie i Oss. 330; uzup. za BOZ 964 i ApP 73.

${ }_{19}$ Tak tedy nasi szlachta... - BOZ 964: Tak tedy nasi szlachta do Moskwy po sukurs, po gwarancyję trafią spod deszczu pod rynnę.

${ }^{20}$ Wszechmocnym - w rpsie: powszechnym; popr. za pozostałymi odpisami.

${ }^{21}$ Aprehendować - w rpsie i BOZ 964: aprendować; popr. za Oss. 330. 
niż Karola Wielkiego. Dom austryjacki świętym zowią na świecie, a nie miał22 tych skrupułów Karol Piąty, powydzierawszy innym dziedzictwa, Czechom i Węgrom zupełnie wolność skasowawszy i zniszczywszy, Rzym nastraszywszy i papieża przez Karola Borboniusza. Wojnę niby z dysydentami prowadził dla swego zysku, bo Leona Dziesiątego, szumnego papieża, na ekspens kilkudziesiąt milijonów czerwonych złotych wyciągnął, włoskich prowincyj przysposobił, a z dysydentami miał umowę, kiedy mógł ich pobić i znieść, to im uciekać pozwalał, spóźniając się z wojska nadciągnieniem. Katolicka liga uwierzyła w niego jak w bożka, a on był największy ${ }^{23} w$ świecie filut. Przeszedł Tyberyjusza $i$ innych zawołanych mataczów, zawziął się na zgubę was, książąt Sasów, zburzył wasze domy, i z tego mu dobrze było, o spokojność i swego majestatu powage, i niby na pozór przeciwko Turkom chcąc wojować czynił te w Niemczech gonitwy przez lat kilka, a przed katolikami udawał, że za wiarę katolicką na zniszczenie dysydentów i na odebranie im liberum exercitium i równości z katolikami. Dawali pomoc i sypali jak piasek pieniądze królowie, książęta katoliccy, duchowni, damy, prywatni nawet bogaci ludzie, a on ze wszystkich drwił i nie szukał publicznego dobra ani triumfu wiary katolickiej jako żywo, ale swojego pożytku. A wszakże on się może nazwać słuszniej niż sam Marcin Luter patryjarchą, ojcem, fundatorem, zaszczepicielem, wkorzenicielem, obrońcą najmocniejszym i opiekunem lutrów in imperio. Konstytucyja jego sławna interim to pokazuje i profesyja wiary ich auszpurgska, kędy on, jakoby papież luterski, słuchał ich artykułów i aprobował je na zawsze. Taki tedy filut był i matacz, byleby panował, Karol Piąty, a przecież miany był za świętego, że ku starości tron cesarski porzucił, lubo tego za kilka miesięcy żałował, do Burgos hiszpańskiego miasta zaraz przyjachawszy, kiedy miasto z rekognicyją ku niemu nie wyszło ${ }^{24}$, i kiedy syn Filip nie dosyłał mu przyrzeczonych pieniędzy, został niby mnichem w klasztorze świętego Justa, płakał, modlił się, pościł, medytacyje odprawiał, dyscypliny czynił, w ogrodzie miejsca święte przez imaginacyją nawiedzał etc., sam za siebie za życia egzekwije sprawował, około trumny z portretem swoim ze świecą chodził, i to dosyć było dla utrzymania świątobliwości, co mu jego kapelani, teologowie, filuty także duchowni opisywali. A co zdarł, to zdarł, co ufundował, to ufundował dom swój austryjacki i zbogacił na wieki; inną to drogą chodzi panowanie rozumne ${ }^{25}$, a inną rzymskiego Kościoła świątobliwość. Co innego są iura dominationis ${ }^{26}$, a co innego akty strzeliste, różańce, ofiary, modlitwy i donatywy kościołom. Subtelna kochanych jezuitów nauka wszystko pogodzi, według ich teologiji można być łakomym, zdziercą, okrutnym razem i jałmużnikiem, i pobożnym, można krzywoprzysiąc, skłamać, uwieść, oszukać z restrykcyją mentalną, a świątobliwość nie stracić. Ich się arkanami dom święty austryjacki rządzi, a ma opiniją katolictwa i wysokiej świątobliwości. Trzeba wiedzieć, że mi to wcale dziwno, iże ty, Auguście, wziąwszy w posagu ‘z żoną twoją, ${ }^{27}$ dwunastu jezuitów,

\footnotetext{
${ }^{22}$ Nie miat - Oss. 330, BOZ 964: nie ma.

${ }^{23}$ Największy - Oss. 330: najgłębszy; BOZ 964: najtęższy.

${ }^{24}$ Nie wyszło - BOZ 964, ApP 73: wyszło.

${ }^{25}$ Panowanie rozumne - Oss. 330: panowanie panującemu pożyteczne.

26 lura dominationis - Oss. 330: arcana dominationis.

${ }^{27}$ Z żoną twoją - brak w rpsie; uzup. za pozostałymi odpisami.
} 
jak zwyczaj był wszystkim Austryjaczkom, żywiąc ich u dworu, ich wolą pełniąc, w Dreźnie ich mimo wolą lutrów fundując najwspanialej, pod ich absolutność poddawszy się, która jest skutkiem grzechu ich pierworodnego, jako mówi o nich pewny mędrzec i rzetelny polityk: „Grzech pierworodny jezuicki jest duch panowania nad Kościołem i światem całym, jest duch mieszania stanu politycznego" - a nie chciałeś ich arkanami i teologiją po austryjacku i na ziemi absolutnego, i w niebie wiecznego dorabiać się królestwa.

\section{August}

Daj pokój jezuitom, i onić już mają za swoje, zarównie teraz na ich uciemiężenie akatolicy i katolicy nawet spiknęli się i sprzysięgli.

\section{Stanisław}

Trzeba dalej czytać te rady.

\section{August}

Jeszcze odczytasz, dosyć tu czasu w wieczności na wszystko.

\section{Stanisław}

To przestanę tymczasem; ale za cóż mi nie każesz mówić prawdy o jezuitach, którzy religiją kręcą jak wietrznikiem u Bożej męki, którzy z wiary katolickiej, pani niegdyś serc i sumnień, uczynili podług interesów świeckich chodzącą niewolnicę, akomodując onę do humorów królów, do potrzeby ich dominacyi i domu swego zmocnienia. Pomijam chińską onę szpetną akcyją ${ }^{28}$, przez którą się u świata zhańbili, kiedy w posągach Konfucyjusza wyrzynać kazali dziury na hostyją, nauczając, iż można czynić dwom razem ofiary, Panu Jezusowi i Konfucyjuszowi, na co dominikanie powstali, i niżeli Rzym tę wojnę uspokoił, tymczasem i tych, i tych z Chin wygnano i wiary katolickiej ${ }^{29}$ pozbyto się, ażeby potym nie było sprzeczek i wojny o religija.

\section{August}

Sa też to po większej części egzageracyje niechętnych ku nim katolików, a najwięcej dysydentów, więcej oni jednakże wierze katolickiej i Rzymowi przysługi uczynili.

\section{Stanisław}

Rzymowi? pozwalam, dlatego też ich cierpi i przeciwko światu całemu katolickiemu wołającemu o zgubę ich zakonu utrzymuje, ale nie pozwalam, aby się Kościołowi katolickiemu przysłużyli, chyba tak jak Dionizyjusz ów syrakuzański przysłużył się Jowisza Hamońskiego złotemu posaggowi, którego z płaszcza złotego odarł, dając przyczyny właśnie jezuickie, że ten płaszcz ani go w zimie zagrzeje,

\footnotetext{
${ }^{28}$ Akcyją - ApP 73: okazyją.

${ }^{29}$ Katolickiej - Oss. 330: chrześcijańskiej.
} 
bo metal zimny każdy, a w lecie cięży, i dlatego sobie złotem, a jemu wełną przysłużył się. Podobniutejkie też ich ku wierze świętej katolickiej i Kościołowi zasługi. Podobna ich moralność, którą napawają serca rządców; Ferdynandowi poradzili, gdy się o królestwo rzymskie starał, a potym o cesarstwo, a widział, że dysydenci równo z katolikami mocni nie dopuszczą go do tego, aby im skrycie per litteras maiestatis et fidei asekurował im ich przywileje, liberum exercitium i zarówno ze wszystkimi katolikami prawa i swobody, ale bez tej klauzuli perpetuitatis i nie determinując nic czasu, skrycie zaś kazali mu tę restrykcyją zachowywać ${ }^{30}$, że do pięciu lat, póki się nie wzmocni. Uwierzył tedy on nieborak ‘tej, ${ }^{31}$ moralności, chwycił się jej żywo, dostąpił, czego żądał, przez ten sekretny kontrakt z dysydentami. Potym, gdy się już na tronie cesarskim utwierdził, przypominają mu jezuici jego restrykcyją mentalną jako powinność katolika najistotniejszą, daje się powodować, rewokuje swoje przywileje et litteras fidei kasuje, wojna poczyna się okrutna i kraju spustoszenie. Otóż przysługa jezuicka jedna ku narodom i wiary katolickiej ruina wieczna ${ }^{32}$, a dysydentów wzmocnienie, ugruntowanie, to druga ich ku wierze katolickiej i ku Kościołowi świętemu usługa.

\section{August}

Wiem ja dobrze, że ty jezuitów nie zażywałbyś do takich robót, a lepiej nad Karola, nad Ferdynandów, Austryjaków jezuitom posłusznych wszystko wykonałbyś, wszakże i dzisiejszy Stanisław Poniatowski bez jezuitów rady, bez restrykcyi ich, bez ich arkanów, a ślicznie naród uwiódł i dysydentom pomógł, a katolicką wiarę na wieki osłabił.

\section{Stanisław}

Ale mu się też tak nie udaje jak tamtym. Darmo, jezuici są do skrytych robót niepoczciwych w świecie najlepsi.

\section{August}

U nas tu słychać, że misjonarz i pijar, sławnych dwóch mędrców w Polszcze teraz arkanami wszystkich jezuitów, którzy byli, są i będą, zakasowali, i że oni Stanisławowi dzisiejszemu królowi polskiemu Pentateuchum opisane; sumnienie mu zregulowali jak zegarek na wykonanie wielkich fortelów i odmiany państwa polskiego $z$ wiarą.

\section{Stanisław}

Nie czyń krzywdy jezuitom. Jest w tej konfraterni mędrców i skrytych konsylijarzów, rządców sumnienia, także jezuita sławny, królewski kaznodzieja; wszyscy ci pro bono publico kooperują mężnie i mocno. I dlategoć słyszę, że imiennik mój, król dzisiejszy polski w swoim gabinecie zawiesił ich portrety pomiędzy Woltera,

${ }^{30}$ Zachowywać - Oss. 330, BOZ 964: utrzymywać.

${ }^{31}$ Tej - w rpsie i BOZ 964 brak; uzup. za Oss. 330.

${ }_{32}$ Wiary katolickiej ruina wieczna - Oss. 330: wiary katolickiej w wielu niemieckich krajach nadwerężenie. 
Russa i Bilfelda portretami, i dał przyczynę jednemu pytającemu się, skądby to braterstwo ludzi sobie przeciwnych religiją - że w jednym są u niego ci wszyscy szacunku, jeden cel wszystkich, jednakoweż nauki, tylko w słowach i kolorach różne, wszystkich tych ${ }^{33}$ polityka nie może być, tylko przez ruinę kraju i krew ludzką uskutkowana.

\section{August}

Ma rozum, słusznie i szczerze argumentuje, znam i ja wszystkich sentymenta, prócz jezuity, któregom z kazań w Marywilu zasłyszał sławy; mnie się zdaje, że nie jest on tęgi polityk, ile że młody, aby pijarowi na przykład, twemu faworytowi, 'wyrównał ${ }^{34}$, któremuś ty biskupstwo poznańskie obiecał, gdybyś się był utrzymał.

\section{Stanisław}

Prawda, że on tych wszystkich trzech przechodzi rozumem; wszak i książki jego w Europie głośne, a u Polaków nienawisne to świadczą, i ja go z rozumu i talentów wielkich polubiłem, skąd gdyby kto chciał tych trzech zażyć duchownych do wykonania jakich odmian i do roboty sławnej, ${ }^{35}$, pijara trzeba by zażyć do dyktowania, do pisania, a tamtych obóch do fakcyi i filuteryi.

\section{August}

Darmo, ty przecież swego faworyta, partyzanta kochasz i ochraniasz, chociażeś się przy koronie polskiej nie utrzymał ${ }^{36}$.

\section{Stanisław}

Wart on tego, bym go szacował z rozumu, mimo interesu mojego. Ale nie rozumiej, aby teraźniejszy imiennik mój, król poiski człowieka tego kochał i słuchał. Chociaż to prawda, że on tak przylgnął do niego, jak do mnie, i zapewne gotuje znowu sobie i swojej kongregacyi nienawiść u domu twego ${ }^{37}$, który zapewne na tron polski powróci się.

\section{August}

Nie spodziewam się ja tego, ani życzę żadnemu z synów moich.

\section{Stanisław}

Ja zaś mówię, że to koniecznie nastąpi. Darmo, wyznać tu musiemy na siebie Stanisławowie, żeśmy szczęśliwi i nieszczęśliwi: szczęśliwi do obrania na tron polski, nieszczęśliwi do utrzymania się przy nim, i podobno na nas zakończy się

\footnotetext{
${ }^{33}$ Wszystkich tych - Oss. 330, BOZ 964: wszystkich tych sześciu.

${ }^{34}$ Wyrównał - brak w rpsie; uzup. za Oss. 330 i BOZ 964.

${ }^{35}$ I do roboty sławnej - brak w rpsie; uzup. jw.

${ }^{36}$ Chociażeś się... - BOZ 964: chociaż cię przy koronie poiskiej nie utrzymał.

${ }^{37} \mathrm{U}$ domu twego - BOZ 964: u dworu twojego.
} 
już na wieki Piasta elekcyja. Lepiej jest, ja sam mówię, cudzoziemcowi być u Polaków królem, i Polakom lepiej jest mieć cudzoziemca.

\section{August}

Na obydwie strony są dosyć pozorne i zarówne przyczyny. Ale za co znowu tak jesteś zawzięty na swego imiennika, za co mu źle wróżysz?

\section{Stanisław}

A za cóżeś ty na swoją własną krew, na ślicznych synów zawzięty? to gorsza wina, niżeli iż ja, jako twierdzisz, jestem nieprzyjazny Stanisław Stanisławowi, lubo ja nic nie mam do niego, i jako sam mi wymawiałeś, winszowałem mu tronu i oświadczyłem mu życzenie, aby talentami swoimi do rządu sposobnymi zaszczycił koronę.

\section{August}

To niech panuje w pokoju i ty trzymaj się jednych nieodmiennych ku niemu sentymentów, ja sam przez miłość ku narodowi polskiemu życzę mu szczęśliwości w zamysłach.

\section{Stanisław}

A już też tu prawdziwie ze mnie i z niego żartujesz. Jakaż to miłość kraju, jakie żądanie twoje szczęśliwości dla narodu polskiego, kiedy życzysz Poniatowskiemu panowania, a sam dotknąłeś już pierwej, że on religiji i wolności, i praw zrujnował całość? Możeż się to jedno z drugim pogodzić?

\section{August}

Jam tylko namienił, i dodałem, że tu tak słychać w naszych cieniach. Bo‘h atyrowie konfederaccy, których tu pełno, tak nam, lubo nie wszyscy, o tym głoszą, bo i z nich kilka mężnie zginęło, ale sami nie wiedzą, o co i za co ${ }^{39}$.

\section{Stanisław}

Tak, tak jest, Auguście, w samej rzeczy ${ }^{40}$. Czegoś ty się bał, choć cię namawiano, na to się ten nieszczęśliwy Polak targnął. Wprzód w Petersburgu uczynił z carową umowę sekretną, że uczyni podług jej woli, co każe. On z wujaszkiem dysydentów zburzył do konfederacyi, on mixtum iudicium uplantował, on znowu przez subordynowane osoby wzburzył gorliwych obywatelów na dysydentów, on tychże samych nabechtał przez swoich sprawców, aby carowej o jego detronizacyją prosili, i aby przez radomską konfederacyją prosili sami o posiłki na niego i na przemocnych wujów, zapobiegając pilnie, aby się do innego dworu Polacy ze skargą nie udali. Tak wszystkich złudził, pomięszał, uplątał i w tę najnieszczęśliw-

\footnotetext{
${ }^{38}$ Na swego imiennika - BOZ 964: na swojego Stanisława.

${ }^{39}$ Bo i z nich kilka... - brak w Oss. 330.

${ }^{40}$ W samej rzeczy - Oss. 330, BOZ 964: w samej prawdzie.
} 
szą, która się dzieje, wprawił rewolucyją. Więc że Polacy bronią się, że interregnum ogłosili i o nowym królu sobie myślą, nie masz co ganić, mają wolność, lubo ja mu jak żywo źle nie życzę, ale nie jestem tak ciemny ${ }^{41}$, abym nie dociekał, co się stanie.

\section{August}

Rzecz wcale niesprawiedliwa spychać kogo z tronu.

\section{Stanisław}

Daj pokój tym skrupułom. Sankcyja pragmatyczna ‘tak` każe i święte domu austryjackiego ustawy.

\section{August}

Wierzaj mi, wolałbym nierównie, aby dzieci moje mało miały, a poczciwości nie stracili i nie narażali się na zgubę wieczną, wolałbym, aby i swoje pretensyje do sukcesyi austryjackiej i koronę polską stracili, niźli miłość Pana Boga, miłość bliźniego i zbawienie duszy.

\section{Stanisław}

O, jakżeś to gorliwy apostoł! Trzeba ci było, jak twój syn Klemens uczynił, zostać księdzem, kiedy tak duchowne masz myśli i o swoje dzieci nie dbasz.

\section{August}

Alboż to tylko sami księża o zbawieniu myśleć powinni? Dzieciom moim da Bóg za to samo, że od dziada przyjętą wiarę świętą katolicką utrzymują nauczeni i zapaleni do niej ode mnie. A choćby im Bóg ${ }^{42}$ nic nie przydał, tedy i na swoim dziedzictwie powinnoby im być dosyć. I tak jeszcze nie staliby się świata tułacza$\mathrm{mi}^{43}$.

\section{Stanisław}

Juże mi tej moralności mówić poprzestań, wiem ja także, co mówię, i przy tym, zobaczysz, utrzymam się. Mało albowiem na tym, że Turcy, którym się teraz dosyć szczęścić zaczyna ${ }^{44}$, nie chcą jego na tronie, a to u mnie jeszcze pewniejszy fundament, że cesarz nie chce także.

\section{August}

O Turkach wiem za pewne, że chcą innego króla, ale o cesarzu nic pewnego nie mam.

\footnotetext{
${ }^{41}$ Tak ciemny - BOZ 964: tak prosty.

${ }^{42}$ Bóg - BOZ 964: Syn Boży.

${ }^{43}$ I tak jeszcze... - brak w Oss. 330.

${ }^{44}$ Którym się teraz... - brak w Oss. 330.
} 


\section{Stanisław}

Cóż pewniejszego nad te dowody? Konfederacka Generalność solennie interregnum ogłosiła, przeciwko królowi manifest wielki napisała gravamina status na familiją jego głosząc, jemu zaś inwazyją i uzurpacyją tronu przyznając ${ }^{45}$ przez flinty moskiewskie na elekcyi, na pseudokoronacyi osiągnionego. A cesarz ich po takich transakcyjach w kraju swoim okrywa i proteguje.

\section{August}

To czynił zrazu i król pruski, a przecie on z imperatorową rosyjską trzyma. I cóż to za pewność? Toć klasztory czasem i kościoły kryminalistów ukryją od zguby zachowując ${ }^{46}$, ale nie idzie ta konsekwencyja, żeby ich potym przy ich zbrodniach utrzymywały i nad poczciwych przekładały ${ }^{47}$.

\section{Stanisław}

Jak miarkuję, żartujesz oczywiście ze mnie, Auguście. Właśnie stałeś się w tym kraju nieśmiertelnym teraz dwornisiem, śmiesznym filozofem i bez aprehensyi politykiem ${ }^{48}$. Na pośmiech jedynie stylem warszawskim dzisiejszym i petersburskim zaczynasz ${ }^{49}$. Tak oni udawali zrazu i o Porcie ottomańskiej głosili po gazetach, komponowali deklaracyje $z$ samego Dywanu stambulskiego, iż nie chce znać żadnych konfederatów polskich za dobrych obywatelów Najjaśniejsza Porta, że zakazuje baszom nadgranicznym, aby im przytulenia nigdzie nie dali jako zburzycielom pokoju i buntownikom przeciwko królowi, swojemu prawemu panu. A to wtenczas szalwierowali, publicznie głosili, udawali na odstręczenie innych do wiązania się, kiedy aga przysłany był do Krasińskiego i Pułaskiego, pierwszych fundatorów, cnotliwych wielkich ludzi, barskiej konfederacyi, do ułożenia punktów, według których najściślej mają się trzymać Turcy z konfederatami przeciwko Mos$k w_{i}{ }^{50}$. A czegoż tymi szalwierstwami dokazali? Oto cały kraj dziś skonfederował się, wszyscy się wpisali $w$ to bractwo ${ }^{51}$ buntowników, burzycielów, swawolnych kup, rabusiów, prócz kilku podłych zaprzedanych dusz, co przy królu i Moskwie siedzą w Warszawie. Ale też tych wszystkich godnymi kar najniesławniejszych sądzi Generalnośćc ${ }^{52}$.

\section{August}

Byle Moskwa ustąpiła i dysydenci uspokojeni zostali, może się naród z królem zgodzi.

${ }^{45}$ Przyznając - Oss. 330: przypisując.

${ }^{46}$ Od zguby zachowując - brak w Oss. 330.

${ }^{47}$ I nad poczciwych przekładały - brak w Oss. 330.

${ }^{48}$ Właśnie stałeś się... - Oss. 330: Właśnie stałeś się w tym kraju nieśmiertelnym politykiem warszawskiej mody.

${ }^{49}$ Zacinasz - w BOZ 964 i ApP 73: zaczynasz.

${ }^{50}$ Przeciwko Moskwie - dalej w BOZ 964: jako przeciwko wspólnemu nieprzyjacielowi.

${ }^{51} \mathrm{~W}$ to bractwo - Oss. 330: $w$ ten związek.

${ }^{52}$ Ale też tych wszystkich... - Oss. 330: ale też o tych wszystkich wie, jak sądzić Generalność. 


\section{Stanisław}

Już nierychło, już są rzeczy tak posunięte daleko przez ogłoszone interregnum, że żadną miarą na stronę Poniatowskiego naprawić się i nastroić nie mogą.

\section{August}

Czemuż to nie? Skasują potym manifest swój cum gravaminibus, odwołają interregnum, na które się prędko i nagle porwali.

\section{Stanisław}

Jak to prędko? Trzeciego roku po konfederacyi zaczętej ${ }^{53}$ i podniesionej, po tylu punktach i prośbach podawanych do króla, na które on głuchym stawał się, nieużytym i nieodstępującym żadnym sposobem od tyraniji przez Moskwę nad wolnym narodem, którego on był obywatelem niedawno, prostym szlachcicem i wiadomym ${ }^{54}$ dobrze prawa jego.

\section{August}

Alboż to podawali jakie punkta królowi konfederaci barscy? Alboż go zapraszali kiedy do związku swojego na Moskwę i dysydentów, burzycielów pokoju? ${ }^{55}$

\section{Stanisław}

Tak jest, nie inaczej, są te punkta, które przez Mokronowskiego zaraz w początkach ${ }^{56}$ podali, drukowane $w$ księdze konfederackiej, są w aktach publicznych Generalności zapisane, nikt onych nie zmaże, nie zaprze.

\section{August}

To co innego święci się.

\section{Stanisław}

Zmyślasz, Auguście, i udajesz niewiadomego daremnie. Wiem, że o tym wiesz równie ze mną.

\section{August}

Ja rozumiałem wcale, że zaraz na początku Krasiński z Pułaskim na króla zażarli się i znowu mało co odmienną scenę od radomskiej grać poczęli, jedynie tylko szukając detronizacyi Poniatowskiego, nie skasowania traktatu i sejmu warszawskiego, nie przywrócenia do swej całości praw, wiary i wolności.

\footnotetext{
${ }^{53}$ Zaczętej - brak w Oss. 330 i BOZ 964.

${ }^{54}$ Wiadomym - Oss. 330, BOZ 964: znajomym.

${ }^{55}$ Do związku swojego na Moskwę... - Oss. 330: do związku swojego, do którego okrucieństwy moskiewskimi przymuszeni byli?

${ }^{56}$ Zaraz w początkach - brak w BOZ 964.
} 


\section{Stanisław}

Tak ci udawało warszawskie contrabando z Moskwą ${ }^{57}$, ale to fałsz wielki, wszak uniwersały pierwsze Krasińskiego i Pułaskiego zwołują naród do obrony wiary świętej, wolności, praw, i o te podeptane, zrujnowane żalą się, słówka jednego na króla nie mają. Toż samo i inszych marszałków powstających ad mentem barskich odwołujących się uniwersały i manifesta jak najskrupulatniej zachowują, manifesta nawet przed zaczęciem konfederacyi Chreptowicza, księcia biskupa krakowskiego, Wybickiego, wszystkie tylko na moskiewskie gwałty pod bokiem króla popełniane żalą się, ale nie przeciwko królowi. Dopiero po punktach i prośbach podanych do tronu, cierpiąc, krew lejąc, kiedy odpowiedzi doczekać się nie mogli przez trzy lata, z interregnum wybuchnęli.

\section{August}

Ja o tych punktach nie słyszałem, owszem nam powiadano, że Mokronowskiego nie przyjęto, na króla zaraz zelżywe podniesiono głosy.

\section{Stanisław}

Nieprawda, sąć tu konfederatów znaczniejsze dusze, to przecie muszą te wszystkie rzeczy z regestru wiedzieć, i z nimi tu dawniej przestajesz.

\section{August}

Prawda, powiadali, ale ja im na tym świecie, chociaż tu prawda mieszka, nawet jeszcze nie wierzę, bo są chwalcy próżni, i jak mi się zdaje, wielcy pływacze.

\section{Stanisław}

Toć tu innych dowodów nie trzeba - oto punkta barskiej konfederacyi podane przez Mokronowskiego, mam tu właśnie ich kopiję przy sobie dla uspokojenia ${ }^{58}$ ciekawości twojej.

\section{August}

Słucham chętnie, muszą być ciekawe.

\section{Stanisław}

Mało na tym, żeby ciekawe tylko były, ale jeszcze arcysłuszne, nie masz co na to mówić. (czyta:) „Primo: Aby wojsko moskiewskie do swojego kraju ustąpiło natychmiast z księciem Repninem, a król jegomość żeby potym na zawsze się wyrzekł przyjaźni moskiewskiej ${ }^{59}$, tak bardzo Rzeczypospolitej szkodliwej. ${ }^{60}$

Secundo: Aby senatorowie i wszyscy więźniowie, gwattownie i bezprawnie pobrani, byli z honorem przywróceni i odwiezieni do granic naszych.

\footnotetext{
${ }^{57}$ Tak ci udawało... - Oss. 330: Tak ci to udawała Warszawa z Moskwa.

${ }^{58}$ Uspokojenia - BOZ 964: ukontentowania.

${ }^{59}$ Moskiewskiej - BOZ 964: rosyjskiej.

${ }^{60}$ Tak bardzo Rzeczypospolitej szkodliwej - Oss. 330: najszkodliwszej i najniebezpieczniejszej dla Polaków.
} 
Tertio: Konfederacyja barska więcej po królu jegomości nie pragnie, tylko zaufania; niechaj postara się odłączyć od Moskwy ${ }^{61}$, niechaj opresyje nasze za słuszne uzna, niechaj łączy się z nami na ocalenie wiary świętej i praw fundamentalnych narodowych, których przestrzegać i pilnować usilnie poprzysiągł.

Quarto: Pragnie tego konfederacyja, aby wszystkie wojska koronne i litewskie złączyły się ${ }^{62}$ na sejm pod Kraków, gdzie congregatis statibus $w$ pryncypalnym miasta kościele król jegomość uczyni profesyją wiary świętej katolickiej rzymskiej głośno, językiem polskim dla oddalenia od siebie złego ${ }^{63}$ porozumienia, i odnowi swoją solenną przysięgę, którą po elekcyi wykonał.

Quinto: Aby na wszystkich osobach cuiuscunque status kara była egzekwowana, jeżeli się w obecności stanów dowiodą im crimina status. A którzykolwiek od Moskwy i dysydentów pobrali pieniądze na opresyją wiary katolickiej i wolnego obywatelstwa, aby one oddali in toto, in quanto wzięli. Kara zaś pro crimine status tak na duchownych, jako i na świeckich niech będzie karą.

Sexto: Dysydentów, którzy konstytucyją sejmu ostatniego komisyi traktatowej podpisali, incapaces omnium bonorum et activitatum deklarujemy, $i$ aby za takowych wyrokiem króla jegomości byli uznani, dopraszamy się.

Septimo: Punkta faworyzujące i przywileje dla dysydentów z ostatniej traktatowej komisyi, jako poniżające wiarę świętą rzymską katolicką, a wywyższające błędy, aby in publico foro spalone były.

Octavo: Nie zamieszkani od dziadów, pradziadów dysydenci, aby wszyscy wygnani zostali z kraju i własnym oddani monarchom, naznaczywszy im czas przez sejm do wywiezienia się. Ci zaś, którzy tu dawno osiedli, zostaną się, aby według traktatu oliwskiego w swoich własnościach żyli beśpiecznie pod jurysdykcyją duchownych katolickich, bez wszelkich urzędów i prerogatyw, z pozwoleniem dla nich prywatnych oratoryjów. Item aby się $w$ wojsku więcej jak do chorąstwa nie awansowali, aby na komorach, żupach, pocztach nie mieścili się, o to najusilniej domagamy się.

Nono: Aby Rzeczpospolita nasza z cesarzem jegomością i królem pruskim przymierze wieczne zawarła dla przyrzeczenia od tych monarchów ${ }^{64}$ pomocy do odebrania awulsów od Moskwy, i na ten koniec aukcyją wojska z okryśleniem żołdu, bez uciemiężenia obywatelów ${ }^{65}$, mocno i jako najusilniej zaleca konfederacyja Jego Królewskiej Mości.

Decimo: Chce, żąda, zaleca to najpierwej konfederacyja, aby zacząwszy od konwokacyi aż dotą ${ }^{66}$ wszelkie nobilitacyje, starostwa, wakanse, honory były konfirmowane lub skasowane, i salva moderatione ${ }^{67}$ bene merentium.

Undecimo: Chce ani tego może odstąpić konfederacyja, aby dawna forma rządu quo ad omnia była powrócona".

\footnotetext{
${ }^{61}$ Niechaj postara się... - Oss. 330: niechaj odstrychnie się od Moskwy.

62 Złączyły się - Oss. 330: złączywszy się.

${ }^{63}$ Ztego - brak w Oss. 330.

${ }^{64}$ Od tych monarchów - dalej w Oss. 330: jeżeli będzie można, pomocy.

${ }^{65}$ Bez uciemiężenia obywatelów - brak w Oss. 330.

${ }^{66}$ Aż dotąd - Oss. 330: aż do tego czasu.

${ }^{67}$ Moderatione - Oss. 330: ratione.
} 


\section{August}

Cóż tedy na to król? co ministeryjum? co warszawskie subijekta?

\section{Stanisław}

Oto sądzili ich buntownikami, garstką ludzi swawolnych, bez czci, bez zasług, bez rozumu ${ }^{68}$, i tak ich do Petersburga opisywali, tak ich nawet po całej Europie głosili, zaleciwszy komendantowi moskiewskiemu, aby ich prześladowali i jak najprędzej wytępili.

\section{August}

To insza rzecz cale. Wychodzę z błędu, usprawiedliwiasz mi teraz dopiero konfederacyją.

\section{Stanisław}

Więcej ci jeszcze powiem, że oni teraz nawet w swoich nowych prawach, które piszą i gotują do nowego sejmu electionis, niektóre konwokacyi teraźniejszej i elekcyi, chociaż uzurpowanej, przepisali w których nic nie znaleźli przeciwnego formie wolnego rządu i prawom kardynalnym fundamentalnym; ale com ci namienił, to jest prawda, iż ekskluzyją chcą na wieki uczynić Polaka od tronu, tedy dla krwi twojej większa nadzieja dziedzicznego tronu w Polszcze.

\section{August}

Bóg by ich skarał, żeby o tym pomyślili. Za cóż to znowu wydzierać Polszcze najszacowniejszy wolności klejnot? Skądby miał syn mój albo wnuk to prawo niesłuszne, niegodziwe do takowej odmiany?

\section{Stanisław}

Otóż cię już draźnić nie będę. Powiem, co dostatecznie wiem, co cię powinno uweselić: Generalność konfederacka chce zaręczyć to in pactis conventis, żeby odtąd sukcesyja domu twojego in maiorennitate ${ }^{69}$ do tronu polskiego była, $z$ asekuracyją wszystkich dawnych wolności i swobód, z odprawieniem ceremonij elekcyjnego sejmu i z nowym zawsze od następcy tronu po ojcu zaprzysiężeniu pactorum conventorum, które salwować sobie chce solennie Rzeczypospolita na zawsze, także asekuracyją konfederacyi jako najzbawienniejszego od przodków podanego środku do utrzymania króla w swojej powinności.

\section{August}

Nic sprawiedliwszego kiedy uważam; to oni coś pięknie i zbawiennie myślą. Nie mówię tu na zalecenie krwi mojej, jeżeli jest to do tronu polskiego przeznaczona, ale szczególnie na okazanie życzliwości ku królestwu całemu polskiemu, którego częsta a największa ruina przez bezkrólewia czas fatalny bywać dotąd zwyk-

\footnotetext{
${ }^{68}$ Bez rozumu - brak w Oss. 330.

${ }^{69}$ In maiorennitate - brak w Oss. 330.
} 
ła, wszak wolności ich nie zaszkodziło, i owszem jej coraz więcej przybywało, chociaż Jagiellonowie syn po ojcu następowali.

\section{Stanisław}

Zapewne, że rozumnie postąpia ${ }^{70}$, jeżeli się na to zgodzą zupełnie, o czym teraz traktują i co jest jeszcze w kwestyjach. Dopiero znowu Polska stanie się Polską więcej jeszcze sławniejszą niż przedtym bywała, kiedy sobie tron na zawsze ubeśpieczy i wewnętrznego chwyci się rządu.

\section{August}

Ale liberum veto jeżeli wróci się, a raczej liberum rumpo, to jest moc przy jednym rwania sejmów, to znowu nieuchybnie jak przedtym nierząd wróci się, znowu Polska stanie się przechodnią kamienicą wojskom zagranicznym, żołnierza swojego mieć nie będzie, skarbu publicznego administracyja nikczemnie, bezpożytecznie, z krzywdą narodu pójdzie, miasta królewskie czyli Rzeczypospolitej spustoszeją, zgoła znowu Polska stanie się (bez pieniędzy, ${ }^{71}$, bez sił, bez rady.

\section{Stanisław}

Jest wielce ta moc potrzebna z prawa jednemu sprzeciwienia się czyli “unanimitas ${ }^{72}$, i słusznie ją Polacy pupillam libertatis zowią, ale aby dobrze rozumiana ${ }^{73}$ i dobrze zażywana być mogła, na to praw i najściślejszego obostrzenia trzeba, bo można mówić, że rozpusta jedyna, chciwość, fakcyje podskarbich i hetmanów przedtym sejmy zrywały, o czym ślicznie bardzo, gruntownie i z serca obywatelskiego napisał rozumny i wielce sławny pijar Konarski, do którego daremną, jak widzę, masz urazę.

\section{August}

Ja zaś i owszem, tę książkę jego o skutecznym rad sposobie na niemiecki język tłumaczyć kazałem i dziwnie mi się, jako cale narodowi pożyteczna, podobała. Któż więcej uczuł żalu z tego obrzydliwego rwania sejmów nade mnie? Właśnie jak na żart i śmiech zbiegałem z Saksoniji, wabiłem cały naród z Litwy, Prus i z najgłębszej Rusi, sto kilkadziesiąt mil jachali obrani posłowie do Warszawy lub do Grodna - po cóż? Oto na urąganie całej Europy, bo po teatrach w Holandyi $i$ innych krajach sejm polski reprezentowali: zjechali się, powadzili się, burd ${ }^{74}$ i hałasów naczynili, jeden skrycie ukradkiem poszedł do kancelaryi, manifest uczynił, sam uciekł, i jużci po sejmie. A tak przez cały przeciąg panowania mego $w$ trzydzieści lat żaden sejm nie doszedł. Toż tedy dziwno nikomu być nie powinno, że podczas rządów moich w Polszcze musiał być nierząd, ktokolwiek to wie, że bez stanów uchwały król w Polszcze malowany.

\footnotetext{
${ }^{70}$ Postapią - Oss. 330: postępują.

${ }^{71}$ Bez pieniędzy - w rpsie brak, błędnie powtórzone: przechodnią kamienicą; popr. za pozostałymi odpisami.

72 Unanimitas - w rpsie: unitatis; popr. jw.

${ }_{73}^{73}$ Dobrze rozumiana - brak w Oss. 330 i BOZ 964.

${ }^{74}$ Burd - Oss. 330: buntów.
} 


\section{Stanisław}

Najcięższa ${ }^{75}$ będzie rzecz dla króla te awulsa Moskalom wydrzeć, a to koniecznie teraz w paktach konwentach podają, i wszystkie krzywdy, które Moskwa poczyniła przez te siedem lat nieszczęśliwe, odzyskać.

\section{August}

Sejm sposób obmyśleć na to powinien.

\section{Stanisław}

Prawda, ale to najwięcej i najszczególniej na królu przyszłym polegać ma. Chcą już teraz Polacy wojować, ale bez swojej szkody i bez podatków, ile przez tę rewolucyją mocno wyniszczeni zostali.

\section{August}

A jakże wojować bez kosztu?

\section{Stanisław}

Nie masz, tylko dwie drogi dla potomka twojego, króla przyszłego: albo uczynić to rozumem bez kosztu, albo uczynić to siłą, męstwem, ale z własnym kosztem swoim. Rozumnie tego dokaże przykładem ojca twego, kiedy za pomocą tak bliskiego ‘a mocnego, kuzyna, cesarza rzymskiego ${ }^{76}$, i innych katolickich medyjatorów przy tym uprze się punkcie w mającym nastąpić traktacie, aby koniecznie co jest polskiego i co trzyma usurpative, oddała Moskwa. Teraz ona pokorna być musi, kiedy na nię potężnie a szczęśliwie Turek następuje, i w Polszcze też jej cale się nie wiedzie. Kochany Pułaski, bohatyr tego wieku najwaleczniejszy, do tego przyszedł dziś stanu, że jej cale nie aprehenduje, a tyle razy, ile porwie się na niego, dobrze jej się da we znaki, zaczym rada nierada musi pozwolić na tę propozycyją przy traktacie oddać, co cudzego. A jeżeliby ten środek nie udał się, czego nie należy spodziewać się, byle cesarz chciał szczerze i do furdymentu ${ }^{77}$ zabierał się, tedy milijonów kilka stracić musi swoich własnych na utrzymanie wojny, na zwerbowanie żołnierza obcego, a osobliwie ${ }^{78}$ na amunicyje i rynsztunki wojenne, bo z nich Moskale wcale wyssali ${ }^{79}$ Polskę. Dzielny Pułaski wartby tego był zaraz, ażeby go generałem en chef uczynić do tej wojny, a potym go buławą, ile że teraz wakują, przez sejm solennie z przyznaniem mu od ojczyzny wdzięczności i udziatu ex pane bene merentium obdarzyć ${ }^{80}$. Będzie to zachęceniem dla rycerstwa młodego polskiego do dzieł wojennych i nauki rycerskiej, kiedy sprawiedliwą tak wielki bohatyr, dziś na cały świat głośny, odbierze nadgrodę, którą wziąć powinien za

\footnotetext{
${ }^{75}$ Najcięższa - Oss. 330: Największa.

${ }^{76}$ A mocnego - brak w rpsie; popr. za BOZ 964, ApP 73; a mocnego kuzyna, cesarza rzymskiego - brak w Oss. 330.

${ }_{77}$ Do furdymentu - BOZ 964: do fundamentu.

${ }^{78}$ Osobliwie - Oss. 330, BOZ 964: mianowicie.

${ }^{79}$ Wyssali - Oss. 330: wybrali.

80 Tu kończy się odpis BOZ 964.
} 
te jego poty, blizny i nieśmiertelne, którymi się wsławił, zasługi. Jemu to sławę, honor i ocalenie wiary, wolności i praw najpryncypalniej Ojczyzna dziś przyznawać koniecznie powinna. Po nim już i innych kilkunastu dobrych, godnych i mężnych $w$ doświadczeniu znajduje się oficyjerów, z których pożyteczną i chwalebną Rzeczpospolita mieć będzie zasługę, kiedy dobrze jak potrzeba zaszczyceni będą.

\section{August}

Ja bym wolał, żeby to w pokoju przy traktatach odzyskać, bo i narodowi zalecitby się król nowy, i przyszedłszy po woli z potrzeby do wojska do porządku na utrzymanie swego dobra odzyskanego, naród przy staraniu króla nowego i nieinteresowanym zaleceniu mógłby dopiero zażyć regularnie sił swoich na nieprzyjaciela napastującego. Bo teraz wszelako dosyć spustoszałą Polskę dalej pustoszyć by potrzeba, ile że namnożyło się hultajstwa bardzo wiele, z którymi by uganiać się i wojować potrzeba, a jeszcze by ich więcej przybywało, gdyby się po tej rewolucyi zaraz wojny nowej otworzyła scena. Będzież to i tak z nimi do czynienia dosyć, niżeli się poskromią i zaspokoją.

\section{Stanisław}

Słuszne żądanie, i Bóg nadzieja, że się uda. Bądźże teraz, Auguście, wyperswadowanym o mnie, że cię kocham, że familiją twoję i krew zacną szacuję tyle, ‘ile Polskę, ${ }^{81}$, ile wiarę katolicką kocham. Nie życzę źle temu teraźniejszemu królowi, ile imiennikowi mojemu i drużbie, ale to znowu jako artykuł wiary szczera prawda, że lepiej życzę wierze i ${ }^{82}$ Rzeczypospolitej Polskiej, która by zapewne pod jego rządem zginęła. On jest jeden Polak, lepiej niech poniesie krzywdę ustępując tronu, niżeli żeby cała Ojczyzna niewinna i krew poczciwa szlachty polskiej na wszystkim ginęła dla jego ambicyi. Darmo, musi się na nim to sprawdzić, co Potocki, pamiętam, napisał:

Kto jest $z$ natury do czapki stworzony, Niechaj swą głową nie sięga korony.

Niechaj będą już odtąd mędrsi Polacy, a na wieczne czasy Polaka ekskludują od tronu.

\section{August}

Mój, widzę, ojciec ku nam idzie, niech też i on tej z przedziwnych sentymentów twoich skosztuje rozkoszy, którą ja czuję.

\section{Stanisław}

Wynidźmy oba ku niemu.

${ }^{81}$ lle Polskę - brak w rpsie; uzup. za Oss. 330.

${ }_{82}$ Wierze i-brak w Oss. 330. 


\section{ROZMOWA DRUGA PO ŚMIERCI MIĘDZY \\ AUGUSTEM II, AUGUSTEM III SYNEM JEGO \\ I STANISŁAWEM LESZCZYŃSKIM, KRÓLAMI POLSKIMI}

Rps AGAD Sucha $248 / 300$ s. 125-187

\section{August III}

Ojcze, wielką przyczynę radości do ciebie ${ }^{1}$ przynoszę, kiedy z tym zacnym gościem, z którym mówić dawno żądałeś, przed tobą staję.

\section{August II}

Stanisława wielkiego oglądam? Onże do mnie pierwszy?...

\section{Stanisław (przerywa)}

Za cóż tyle czynisz podziwienia, gdy mnie widzisz Auguście, większy nad możność ${ }^{2}$ sławienia i przez siebie, i przez syna w całym świecie głośny? Czemuż tyle mi czynisz $z^{3}$ oświadczenia, ilem niegodzien za urazy, którem ci wyrządził?

\section{August II}

Nie pamiętam żadnej urazy.

\section{August III}

Wielka dobroć i cnota pokazuje się, Stanisławie, kiedy nas przepraszasz za to, coś czynić koniecznie był powinien. Co albowiem wieczne wyroki przeznaczą komu, to koniecznie dziać się musi i dokonać niezawodnie. My, ludzie, jesteśmy tylko instrumentami, a Najwyższy Mocarz równie monarchami i poddanymi jak piłkami ${ }^{4}$ rzuca według wiecznych ustaw swoich.

\section{Stanisław}

Ach! przecież to śliczna krew, pańska dobroć i godna w całej Europie panowania, książąt saskich. Widzę dopiero, że ci się narodzili dla czynienia ludziom dobrze, ci są, których popędliwość do zemsty nie porusza, i którzy tkliwi być nie mogą, chyba jednym ludu sobie powierzonego upadkiem. Nie tak jak inni dziś w Europie panujący królowie, u których cel jedyny szczęścia i wielkości ich - potargać społeczeństwa związki, na ruinach i obarczeniu wolności i swobód narodowych ${ }^{5}$ fundować moc i trwałość panowania swego.

\section{August II}

Twoje cnoty, Stanisławie, wmawiasz w nas koniecznie.

1 Radości do ciebie - ApP 73: dla ciebie radości.

${ }^{2}$ Auguście, większy... - ApP 73: Auguście wielki, nad możność...

${ }^{3}$ Mi czynisz - ApP 73: nie czynisz.

${ }^{4}$ Piłkami - ApP 73: piełkami.

${ }^{5} \mathrm{Na}$ ruinach i obarczeniu... - ApP 73: na ruinach wolności i obarczenia swobód narodowych. 


\section{Stanisław}

Nie mam żadnej przyczyny. Wszystkie pasyje, które śmiertelnych ludzi zaślepiają ${ }^{6}$, nas, nieśmiertelnego kraju mieszkańców, już opuściły; mówię to, co mi słuszność każe.

\section{August II}

Wierzaj mi, Stanisławie, że bardziej tkliwy byłem twoim nieszczęściem, żeś dla mojego ucalenia honoru na swoim honorze pokrzywdzon być musiał, lecz byłem na opaczną fortunę gotów. Gdyby twój bohatyr i przyjaciel ${ }^{7}$ serdeczny nie został ze wszystkim pognębiony pod Pułtawą (sic!), a ja nie byłem przyniewolony przez potencyje europejskie, mianowicie zaś przez Moskwę, powstać znowu przeciwko traktatowi gwałtownemu alt-ranstadzkiemu, pewnie byś był z mojej strony spokojnie panował. A jakom ci raz w Alt-Ranstadzie uczynił przyznanie tronu i solenne powinszowanie, $z$ wyrzeczeniem się korony polskiej, tak cię upewniłem, iżbym był nigdy po nią nie sięgał.

\section{Stanisław}

A jakież dla mnie być mogło prawo do spokojnego i chwalebnego panowania, strąciwszy prawnie panującego, skoligowanego z królami w Europie króla mądrego, walecznego i sprawiedliwego?

\section{August II}

Takie byś miał prawo przez moc Szwedów, jakie ja przez moc i broń moskiewską ${ }^{8}$, a gdyby ci się było udało, tobyś szczęśliwszym stał się ode mnie.

\section{August III}

Więcże już nie masz na świecie sprawiedliwości, tylko ta jedna zwierzęca moc, gwaft, rabunek, morderstwa i okrucieństwa prawa dyktować powinny?

\section{August II}

Powiem ci jeszcze prawdę, Stanisławie, i szczerze ci wyspowiadam się myśli moich, żem ja zaraz wszedłszy w siebie, będąc z Polski do Saksoniji wygnany, ukorzyłem się przed Bogiem, Panem Mocarzów, i uznałem Jego sprawiedliwość w tym samym zuchwałym przez Karola spędzeniu mnie z tronu polskiego; rzekłem w skrytości serca mego: „Słuszny jesteś i sprawiedliwy, Boże, w sprawach Twoich. Jam wydarł berło Jakubowi Sobieskiemu królewicowi polskiemu mocno zaleconemu i więziłem go wraz z bracią w Saksoniji, teraz mi go znowu wydziera Karol, obległszy mnie i ścisnąwszy w moim dziedzicznym kraju".

\footnotetext{
${ }^{6}$ Zaślepiają - ApP 73: zastępują.

7 I przyjaciel - brak w ApP 73.

${ }^{8}$ Moskiewską - ApP 73: Moskalów.

${ }^{9}$ Dziedzicznym kraju - ApP 73: dziedzicznym saskim kraju.
} 


\section{Stanisław}

To być nigdy nie mogło, aby Polak natenczas miał królować. Kto pamięta okoliczności przed twoją elekcyją, wspomnieć może owe publiczne pismo do druku podane, rozrzucone podczas konwokacyi po śmierci Jana, że ekskludowany koniecznie powinien być od tronu Piast. Wszak to pismo w konwencie bernardynów na Przedmieściu Krakowskim było zaprzysiężone od siedemdziesięciu kilku znaczniejszych osób i tak wzburzyło obywatelów, że gotowi byli sami się wyrżnąć i wygubić do jednego Polacy, ażeby tylko Polak w Polszcze nie był królem, tak im obmierzło rodaka panowanie.

\section{August II}

Cóż to pismo i sprzysiężenie kilku ważyć mogło przeciwko narodowi, przeciwko sprawiedliwości, przeciwko prawu ${ }^{10}$ i pożytkowi publicznemu Rzeczypospolitej?

\section{Stanisław}

A cóż to za pożytek natenczas mógł być spodziewany, pytam ja się znowu, przez rządcę Polaka?

\section{August II}

Taki, jaki był pod Sobieskim poprzednikiem moim, a sławnym w całej Europie wojownikiem. ${ }^{11}$

\section{Stanisław}

Chyba też taki! To już oczywiście żartujesz, alboż to Sobieski co godnego wspomnienia uczynit dla Polski?

\section{August III}

Bardziej ty żartujesz, Stanisławie, dosyć uczynił, kiedy się nikomu rządzić w Polszcze nie pozwolił, i zaniósł orły polskie, z męstwem i walecznością płosząc nieprzyjaciół ${ }^{12}$, za Dunaj, Dniestr i w odległe ${ }^{13}$ kraje.

\section{Stanisław}

Łatwo to natenczas stać się mogło, i choćby się to nie stało, Polska by na tym nie szkodowała, a gorsza nierównie i jawniejsza Ukrainy, Podola znaczniejszych części wraz z Kamieńcem Podolskim, jedyną fortecą, stała się utrata przez jego dumę i niespokojność.

\section{August III}

Mógłby on to był wszystko odebrać, i co większa, jeszcze zyskać, gdyby był pożył.

\footnotetext{
${ }^{10}$ Przeciwko prawu - brak w ApP 73.

11 Wojownikiem - ApP 73: wojennikiem.

12 Płosząc nieprzyjaciół - w ApP 73 ujęte w nawias.

${ }^{13}$ Odlegte - ApP 73: odleglejsze.
} 


\section{Stanisław}

Nie mógłby zapewne, i gdyby twój ojciec przez wziętość i powagę swoją traktatem karłowickim spokojnie tego Polszcze nie przywrócił, nie byłaby panią dziś Rzeczypospolita tej fortecy z utraconymi krajami.

\section{August II}

Los wojny różny bywa i co jedna wydrze godzina, to druga z korzyścią nadgrodzić może. I o dzisiejszych, które się dzieją w Europie przez Moskwę, korzyściach nad Turkiem nie trzeba rozumieć, że będą stałe i gruntowne, tym samym, że naród, który co wydziera narodowi, już sobie kupuje niepokój i robi z sąsiada poprzysiężonego ${ }^{14}$ dla siebie nieprzyjaciela.

\section{Stanisław}

O losie wojny sprawiedliwej nie wątpię, że ta po różnych burzach szczęśliwym pospolicie kończy się skutkiem, do którego pograniczni sąsiedzi dopomagać muszą. Ale to nie jest zdanie o wojnie niesprawiedliwej, jaką Sobieski z Turkiem prowadzit.

\section{August II}

Możeż być wojna niesprawiedliwsza, jak była turecka, nie tylko przeciwko Leopoldowi cesarzowi, ale też przeciwko całemu chrześcijaństwu podniesiona, z usiłowaniem wytępienia chrześcijan i zniszczenia Chrystusa religiji? A Jan Sobieski chcąc suttana, całej Europy inwazora, okrutne wstrzymać zapędy, chcąc chrześcijaństwo zasłonić i utrzymać oraz sławę imienia polskiego, począwszy chwalebnie pod Widniem, wciągnąc się rad nierad musiał dalej w potrzebę z Turkiem wojowania. Toż tedy gdy Turków niesprawiedliwa była wojna, Sobieskiego z przeciwnej strony przy chrześcijaństwie stojącego sprawiedliwa być musiała.

\section{Stanisław}

Kolory to tylko i udawania były, a w rzeczy samej inna polityka inszy koniec i cel Sobieskiego.

\section{August II}

Nie rozumiem, ani dościgam, chyba mię nauczysz tak, jako sam dobrze przenikasz wszystkie rzeczy.

\section{August III}

Narabiasz, widzę, ojcze, kwitnącą dziś w Europie, a mianowicie w Moskwie obojętnością, wstawiasz tam pozorne sprężyny, gdzie nikczemne machiny i żadną miarą do obrotu nie są zdolne. Czynisz to znać nie dufając Stanisławowi, za którym z gruntu serca ręczę, że jest szczery i naszemu domowi rzetelnie sprzyjający. Można mu teraz dowierzać i z nim tak otwarcie mówić, jak sam w sercu przekonany jesteś.

\footnotetext{
${ }^{14}$ Poprzysiężonego - ApP 73: przysięgłego.
} 


\section{Stanisław}

Wielce o to proszę i za dowód to poczytam przyjaźni waszej. Dacie przez to samo początek dalszych zabaw naszych, gdy ze mną szczerze postępować będziecie, bo ja i w życiu śmiertelnym obłudy nie lubiłem.

\section{August II}

Zgoda, zgoda, przystaję na to, ale pierwej słucham mile rozpoczętej od ciebie nad wojnami Sobieskiego uwagi.

\section{August III}

I ja z tego niewymownie kontent będę, że od was starszych nauczę się, co mi za życia ciemno zdawało się, bo miałem to za skrupuł ciężki tknąć sławy Sobieskiego.

\section{Stanisław}

Nie masz go tu, chwała Bogu, możemy dla wyłuszczenia prawdy pomówić o nim, co słuszność każe. Był to król przez rozum i męstwo godzien panowania, ale potym polakieria wzięła przemoc nad nim, to jest chciwość nienasycona, bo starostwa sam trzymał na siebie co najlepsze, a drugie żonka cudzoziemcom i Żydom, arendowała. Otruła serce jego ambicyja ${ }^{15}$, bo równości i wolności polskiej knował upadek a tych cale sobie obrzydził obywatelów, którym był równy przed wstąpieniem ${ }^{16}$ na tron. Tak to pospolicie bywa, z niższego szczebla razem wysoko postąpić. Bodaj się zawsze święcili królowie z królów wiem, że się na ten mój sentyment dzisiaj wszyscy by zgodzili Polacy. Niespokojność także w swoim stanie hipokondrykiem go uczyniła, bo mu koniecznie jak wóz siana wjachało w głowę obszerniejsze w Europie panowanie. Żonka też jego odrodna od francuskiej poczciwości, wielki szacher, filutka i najobłudniejsza kobieta poddymała mu próżne myśli i nastruszała czuprynę podgoloną do projektów tak szalonych, na jakie się dziś imperatorowa rosyjska w Europie zakasała...

August III' ${ }^{17}$ (przerywa)

Ach, cóż to za żywe wyrażenia twoje, Stanisławie! jakże ty cudnie rzeczy malujesz!

\section{August III}

Nie przeszkadzaj ${ }^{19}$, ja przyznaję już, że mówi rzetelnie, tak jak głęboki i szczery polityk.

\section{Stanisław}

Jużeście mnie zmięszali mowę, nie wiem, jak trafić do składu.

\footnotetext{
${ }^{15}$ Otruła serce jego ambicyja - ApP 73: Otruła serce jego ambicyją...

${ }^{16}$ Wstąpieniem - ApP 73: wzięciem.

${ }^{17}$ W ApP 73: 2gi.

${ }^{18}$ W ApP 73: 3ci.

${ }^{19}$ Nie przeszkadzaj - ApP 73: Nie przeszkadzaj, ojcze.
} 


\section{August III}

Oto masz nam wyprowadzić porównanie szumnych projektów Sobieskiego do projektów dzisiejszej szumnej także Katarzyny, sławnej miłośnicy narodu ludzkiego, rosyjskiej imperatorowej.

\section{Stanisław}

Tak jest kubek w kubek, toż samo działo się w Sobieskiego głowie, co u dzisiejszej imperatorowej. Jej się zachciało na północ sobie uczynić monarchiją większą nierównie, niżeli jest zachodnia rzymska. Toż samo zamyślał Sobieski. Ona na Portę dlatego porwała się przenikając, że wydoła ${ }^{20}$ utrzymywać się z rzymskim cesarzem przeciwko niej, gdy wspólna obrona powagi i mocy ich umówiona między nimi stanie się. Toż samo uplantował sobie Sobieski, aby monarchiją na wschód obszernie rozciągnął, koniecznie usiłował wydrzeć Turkom gwałtem, cokolwiek mają w Europie, i podzielić to między trzech synów i pana de Conti, siestrzeńca żony swojej. On tychże chciał zrobić wasalami swymi i elektorami, a siebie cesarzem. Imperatorowa dzisiejsza rosyjska toż samo uczynić zamyślała ${ }^{21}$ z królami polskim, szwedzkim, duńskim etc., podciągając ich pod swoją dependencyją i władzą. Ta z królem pruskim dzisiejszym chociaż niechętny, przecież potrzebny zawarła alijans, wiedząc, że by on mógł jej przeszkodzić i mógłby, gdyby chciał, zawsze przerzedzić Moskwę, jako niedawno pod Kistrynem, lubo on żadną miarą życzliwym od serca nie może być ku niej przyjacielem, przenikając najprzód, jako rozumny monarcha, co ona zamyśla, po wtóre pomniąc o krzywdach swoich przez Moskwę poczynionych, kiedy Prusy jego podczas ostatniej wojny arendą, ale bez kontraktu i pieniędzy trzymała, a swoim zwyczajem zrabowała, zdarła, zniszczyła lub rozpędziła, i kraj na wieczne niepowstanie zubożyła. Ma jeszcze nadzieję, co większa, imperatorowa, że dopomoże szczerze ten potężny monarcha jej Turków i Polaków uspokoić, którzyby zawsze opierali się przemocy i nowej absolutności tej fundatorki północnego cesarstwa. Ale się, Bóg nadzieja, tak zawiedzie, jak Sobieski na Moskwie ${ }^{22}$.

\section{August II}

To prawda nieomylna, nie jest tak tępy i w ciemię bity król pruski, żeby ślepo sam na siebie miał kuć kajdany. Ale wróć się ty jeszcze do swego Sobieskiego.

\section{Stanisław}

Toż samo, mówię, świszczypałka, pretendowany wschodni cesarz Jan Sobiesio czynił, choć nieszczerze, z Moskwą przez owe z nią umowy niecnotliwe, podłe, obrzydłe i krzywdzące nieskończonym sposobem Rzeczpospolitą Polską, byleby mu taż Moskwa Turków pokonać i z Europy wygnać dopomogła.

\footnotetext{
${ }^{20}$ Że wydoła - w rpsie: że wydoła Porta; popr. za ApP 73.

${ }^{21}$ Zamyślała - ApP 73: zamyśliła.

${ }^{22}$ Ale się, Bóg nadzieja... - ApP 73: Ale się, Bóg nadzieja, tak zawiedzie na królu pruskim, jak Sobieski na niej [!].
} 


\section{August III}

Nie wspominaj tego andruszowskiego traktatu, na którego wspomnienie zawsze drżałem i pragnąłem wynaleźć jaki sposób do zagładzenia onego, luboć on w samej rzeczy ważyć nie powinien, bo go Rzeczypospolita Polska nie przyznała, ani ja, ani mój ojciec nie potwierdziliśmy go, widząc tak ciężką dla Rzeczypospolitej Polskiej w oderwaniu od niej trzech województw: kijowskiego, smoleńskiego i czerniehowskiego «stratę ` ${ }^{23}$, z częścią bardzo znakomitą handlową i najbogatszą Inflant.

\section{August II}

Cóż po tym, chociaż Rzeczypospolita dawniej nie przyznała i na sejmie żadnej o tym wzmianki nie masz na naszej pamięci, kiedy teraz, słyszę, na sejmie elekcyi dzisiejszego Stanisława przez kooperacyją zdrajców Ojczyzny, Czartoryskich, już ten traktat potwierdzony został i przyznany jest imperatorowej tytuł całej Rosyi.

\section{August III}

Ale rewers solenny dała na siebie imperatorowa, że się nigdy do Rusi Polskiej interesować nie będzie.

\section{August II}

Ale to tak będzie prawda, jak wszystkie deklaracyje dla Polski, w których się ogłasza z przywiązaniem do narodu polskiego i z nieinteresowaną troskliwością o ucalenie jej dobra, a tymczasem chyba szatani ${ }^{24}$ sami z piekła wypuszczeni bardziej by kraj polski pustoszyli jako jej wojska.

\section{Stanisław}

Oj, co filut, to filut, i niezrównanej z nikim ${ }^{25}$ chytrości baba. Tak umie ${ }^{26}$ ująć obietnicą napuszoną, wielkością daru ludzi oświeconych nawet, że ich zamota, zaślepi i wprowadzi w niewywikłane labirynta.

\section{August III}

Pokazuje się to oczywiście ${ }^{27}$ na Polakach.

\section{Stanisław}

Nie tylko na Polakach, ona i królowi pruskiemu przyrzekła Prusy polskie, byleby jej teraz, kiedy na nię ${ }^{28}$ ciasno, ten straszny potencyjom wojennik nie odstępowat.

\footnotetext{
${ }^{23}$ Stratę - w rpsie i ApP 73 brak.

${ }^{24}$ Szatani - brak w ApP 73.

${ }^{25}$ Z nikim - ApP 73: nigdy.

${ }^{26}$ Umie - brak w ApP 73.

${ }^{27}$ Oczywiście - ApP 73: najoczewiściej.

${ }^{28} \mathrm{Na}$ nię - w rpsie: na nas; popr. za ApP 73.
} 


\section{August II}

Od śmiechu wstrzymać się nie mogę nad chytrością tej kobiety, jaka to jałmużnica z cudzego worka, jak wspaniała w darach, które ją nic nie kosztują!

\section{Stanisław}

Dalibóg, otworzę wam tu myśl moją jedynie przez żart, wiem albowiem, iżeście dobrzy obydwa katolicy. Gdym posłyszał, że ona królów egipskich stwarza w Egipcie nie swoim, gdy Aleksemu Orłowowi nadała księstwo macedońskie, do którego najmniejszego prawa nie miała, i patentami generałów swoich instalowała na gubernije prowincyi, które są po dziś dzień w mocy tureckiej, zdaje mi się, iż naśladuje papieża rzymskiego, naszego monarchy duchownego, w rozdawaniu biskupstw in partibus i arcybiskupstw w tych krajach, gdzie nie masz nawet słychu o chrześcijaństwie i Rzymie.

\section{August II}

Ale to niemała szkoda, com za pewne słyszał od dzielnych konfederatów, z którymi lubię przestawać, że oryginał autentyczny rewersu imperatorowej i inne wielce potrzebne dla Rzeczypospolitej oryginały spalił w Zamku warszawskim niedawno płochy i nikczemny człowiek Barnawal, Francuz, sekretarz królewski.

\section{August III}

Któż temu winien, kiedy takimi filutami ${ }^{29}$ król otoczonym być lubi i na ich radzie polega. Słyszałem i ja śmieszną rzecz, że książę kanclerz litewski po spaleniu Zamku temuż Barnawalowi kilkaset czerwonych złotych dał jałmużny. Co w tym za tajemnica, odkryje to czas przyszły.

\section{Stanisław}

Otóż to panowanie Polaka ${ }^{30}$, sami widzicie, że żadną miarą pod nim Polska szczęśliwa być nie może, i że imperatorowa rosyjska chciała koniecznie Polskę poniżyć i pod swoję moc podbić, dlatego też Polaka na tron jej narzuciła.

\section{August II}

Krzywdę czynisz narodowi twojemu, alboż to i Polacy nie są ludzie panowania sposobni? A wszakże tyle Polaków było wielkich królów?

\section{Stanisław}

Pokazałem jawnie na Sobieskim, jaka krytyczna epoka była dla Polski podczas rządu jego.

\section{August II}

Jakożkolwiek bądź miał swoje przywary Sobieski, ale też za nieroztropną imprezę jego dało mu się zewsząd we znaki, wniwecz się obróciły jego szumne

\footnotetext{
${ }^{29}$ Filutami - ApP 73: fiutyńcami..

${ }^{30}$ Otóż to panowanie Polaka - ApP 73: Otóż panowie Polacy.
} 
i bardzo daleko sięgające projekta, i Turek się nie dał, i Moskwa go zwiodła, i Polacy, poznawszy chciwość jego, nowe także na wolność zamachy, cale go znienawidzili. A kiedy chcecie wiedzieć, już już podobnie właśnie jako dzisiejszy Poniatowski zachwiał się na tronie. Już mnie samego, jeszcze naówczas dysydenckiej religiji trzymającego się, do tronu wabiono. Jakoż na kilka lat przed śmiercią Sobieskiego, za życia jeszcze brata mojego Jerzego Czwartego w Saksoniji panującego, podczas wojażu w Koloniji błędy luterskie rewokowałem i od papieża sekretnie odebrałem tronu polskiego powinszowanie, co mi potym bardzo pomogto nawet przy stwierdzeniu sankcyi pragmatycznej dla syna mego utrzymania przy tymże tronie. Ale to wszystko pominąwszy, Sobieski był wojennik z chwałą narodu polskiego i jeden z królów wielkich. O, gdyby on dziś zmartwychpowstał z Hektorami swymi: Jabłonowskimi, Potockimi, Sieniawskimi, Koniecpolskimi, Gnińskimi, Denhoffami, Konckimi ${ }^{31}$, biłby zapewne solennie Moskwę, chociaż się z nią niegdyś pokumał, i spychałby ją co żywo z karku wolnego narodu, który osiodłała przez swoją nieczystą gwarancyją i protekcyją wysoką.

\section{August III}

Ale że król śpi na to wszystko, jakoby go nic nie dotykało i zniewaga narodu była daleko od niego.

\section{August II}

Dobrze go też kamieniecki biskup tuzem żołędnym nazwał w liście swoim do Czernego pisanym. Bo cóż on więcej figuruje? Oto jest na kształt podstarościego u Moskwy, Polska zaś jest dziedzicznym i poddanym kluczem Moskwie.

\section{Stanisław}

Pewnie byś i ty, wspaniały Auguście, kochający i twoją własną, i narodu polskiego sławę, ścierpieć tego nie mógł, co ten cierpi, i właśnie jak strugany dziadek pozwala co chciećc ${ }^{32}$ czynić Moskwie. Na co by ci wskrzeszać twoich Maurycych de Saxe, Filiturnów, Flemingów i innych; waleczny Pułaski, Potocki, Zaremba i innych wielu z dzisiejszych konfederatów, gorliwych i przywiązanych do szczęścia Ojczyzny niewysławionych rycerzów, głośnych w Europie, chociaż ich wszystkie czyny Moskwa i bando ${ }^{33}$ warszawskie czerni. Przyłączywszy do nich kilka tysięcy mężnych Sasów, pewnie by cię do Petersburga odprowadzili, przy takiej zwłaszcza armorum dywersyi, jako dziś Porta czyni tak dalece, że Moskwa rady sobie dać nie może.

\section{August II}

Już rozumiem, do czego ciągniesz, daj pokój, proszę.

\footnotetext{
${ }^{31}$ Konckimi - ApP 73: Kąckimi.

${ }^{32}$ Co chcieć - ApP 73: co chce.

${ }^{33}$ Bando - $w$ rpsie: bandau.
} 


\section{August III}

I ja toż samo pojmuję, ale lepiej porzućmy to.

\section{Stanisław}

Nie, nie, jak żywo, choćbyście mi gębę zaszyli, to ja znakami jeszcze pokazować będę, że Sas w Polszcze będzie na tronie, wasz potomek, a ten koniecznie musi być znowu Moskwie nieprzyjacielem.

\section{August II}

Proszę, odstąpmy od tej propozycyi, co nam po tym, przed niewodem, jak mówią, ryby łowić. Przyszłych rzeczy uskutkowanie do samego Boga należy. My się raczej przeszłych rzeczy pożytecznym zabawmy rozważaniem. To rzecz pewna, że ja sam już już zaledwie nie porwałem się na Moskwę, chociażem z Piotrem Wielkim i dawniej w różnych niemieckich miastach, i potym w Rawie, bełskiego województwa miasteczku, już za panowania mego w Polszcze najściślej z nim sprzyjaźnił się. Bo czyliż to nie były znakomite od niej dla mnie afronty, dawać mi prawa, abym z Turkiem nie zawierał przyjaźni, wojska często w granice wpuszczać polskie, krzywdy czynić, na komisyjach zesłanych łudzić i oszukiwać? A że prawdę (o czym teraz może wątpicie) powiem, moskiewskiej to skrytej roboty był skutek tarnogrodzka konfederacyja i Szaniawskiego biskupa krakowskiego zelosia o zwinienie chorągwi, owe Sapiehów w Litwie burdy i inne przysmaczki, ażeby mnie trzymała w upokorzeniu, a kraj do nierządu, do niemocy powoli nakłoniła.

\section{Stanisław}

Prawda szczera, mówisz teraz, Auguście, tak, jak ci rozum i serce każe. A przeto wierzyć temu należy, że chociażby teraz w tych krytycznych na Polskę czasach, po tej tak strasznej dekadencyi i upadku wszystkiego i potomek twój panował nawet, nic by nie wskórał kiedy jak żądała Moskwa, zrobiła Poiskę bez sił, bez pieniędzy, bez amunicyi, burdelem jednym i przechodnią kamienicą.

\section{August III}

Przecież musiałoby być inaczej, musiałby otrząsnąć ‘się) i trzymać z narodem tak ciężko pokrzywdzonym.

\section{Stanisław}

A gdyby też nie chciał łączyć się z narodem?

\section{August III}

To by się łączył z Moskwą jak dzisiejszy Poniatowski, i tak też musiałby się upodlić i cały na siebie oburzyć naród, a potym stracić koronę, poczciwość i honor na wieki ${ }^{34}$.

\footnotetext{
${ }^{34}$ Proszę, odstąpmy od tej propozycyi... - ... i honor na wieki - brak w ApP 73.
} 


\section{August II}

Dobrze, synu mój, mówisz, żyje, widzę, w tobie krew moja, żyje serce i przywiązanie «szczere ${ }^{35}$ do polskiego narodu, którego szczęście poczytałbym teraz przyczynieniem mojego szczęścia, a upadek jego nawet w tych błogosławionych krainach czynitby mnie melancholikiem i zgryzionym na zawsze.

\section{Stanisław}

Tak to się mówi, a moskiewskie karabiny i bagnety co inszego by ${ }^{36} \mathrm{w}$ tamtym życiu perswadowały.

\section{August II}

Temu by wyperswadowały ${ }^{37}$, który przez podłość i najniegodziwsze stopnie pnie się do korony, który więcej waży sobie interes prywatny, aniżeli dobro ludu wolnego.

\section{Stanisław}

Nie do mnie ta jest mowa.

\section{August II}

Ani też do nas.

\section{Stanisław}

A przecież daliście się Moskwie jak szarej gęsi rządzić po morzu, musieliście podlegać jej i zarzucić w Polszcze wojenne dzieła ${ }^{38}$. Musieliście utrzymywać nierząd, i według przepisów tejże Moskwy w gnuśności, bezprawiu, do tego powoli stanu nachylać Polskę, w jakim dziś według żądania dawnego Moskwy zostaje.

\section{August III}

Nie przypisuj nam tego, ale samym Polakom, myśmy o pomnożenie wojska wołali, myśmy fortece stawiać chcieli, na koniec, myśmy żadnego sejmu nie zerwali.

\section{Stanisław}

Trzeba było skuteczniejszych sposobów.

\section{August II}

Ale też trzeba było i na to pamiętać, co polityk napisał: violenta imperia nemo continuat diu. Wolność polską kochaliśmy, najmniejszy ${ }^{39}$ cień samowładności zdawał nam się kryminałem. A chociaż Moskwa niby nam sprzyjała, przecież to praw-

${ }^{35}$ Szczere - brak w rpsie; uzup. za ApP 73.

${ }^{36}$ By - ApP 73: zapewne.

${ }^{37}$ Wyperswadowaty - ApP 73: perswadowały.

${ }^{38}$ I zarzucić w Polszcze wojenne dzieła - brak w ApP 73.

${ }^{39}$ Najmniejszy - ApP 73: a najmniejszy. 
da, że ona własnego szukała interesu i chciała gwałtem dzielić nas z narodem, ażeby jej się w zamęcie lepiej poławiało.

\section{August III}

Tak, nie inaczej, świadkiem ja tego jestem najlepszym, kiedy zamyślając Moskwa uczynić pustyniją w Polszcze przez niezbożnych Czartoryskich, użyła ich fakcyi i szacherstwa na wzburzenie narodu przeciwko mnie tak dalece, że ledwo o włos już mnie nie detronizowano ${ }^{40}$. Ale wzywam Boga na świadectwo, że wolałbym był tronu ${ }^{41}$ odstąpić, niżeli ten naród Moskwie poddać, jako Poniatowski uczynił.

\section{August II}

Toteż sobie zaszkodził, bo go nikt z rozumniejszych i poczciwszych w Europie ludzi poważać nie może. Oprócz tego, co mi to za smak w panowaniu chodzić jak szkapie po cuglach cudzych, nie mieć u poddanych miłości, być zawsze pod młotem grubego narodu i właśnie siedzieć pod mieczem na tronie, a jeszcze pod mieczem na włosku zawieszonym, jako ów Damokles nieszczęśliwy w dostapionym żądanym szczęściu. Ja nie wiem, co to się dzieje w sercu niektórych ludzi dziś na świecie żyjących, że z cygaństwa politykę sobie zrobiwszy, od cnoty, od poczciwości i religiji odstępne mając projekta, metafizyczne, niedościgłe knują sobie i formują końce.

\section{Stanisław}

$\mathrm{Ba}$, i owszem ślepo wszystko czynią, im się oni bardziej rozumnymi ‘czują ${ }^{42}$ i ogłaszają, im usilniej uwielbienie ${ }^{43}$ imienia swojego wrazić chcą w serca rozsądnych ludzi, tym bardziej nikczemnieją i sami się potym wywikłać nie mogą z gęstych sideł szalbierstw i obłudności swoich. Carowa dzisiejsza męża zgubiła z tronu zrzuconego, odsądzonego od siebie za profanowanie starożytnej moskiewskiej religiji i duchowieństwa i zaplenienie dysydentami narodu, a w Polszcze o podwyższenie dysydentów wojuje; tam ich na czas dla interesu nie lubiła, tu dla miłości ich wszystko traci. Taż sama cnotliwa pani, narodu ludzkiego miłośnica, zabić kazała Iwanowicza do tronu sukcesora, a udawała przed światem, że to mimo woli jej stało się. Cóż to, proszę, za związek między tymi filuteryjami?

\section{August III}

Nabili sobie głowę panujący ludzie, że interesa ich na skrytych osadzone sprężynach tym lepiej pójdą, im się dalej odsuną od religiji. A tymczasem to się prawdzi, co uczony napisał Bellegarde, iż śmieje się Bóg z figlarnej tych panów polityki, która albo odłączona jest od religiji, albo ją do interesów swoich nakręcają.

\footnotetext{
${ }^{40}$ Detronizowano - dalej w ApP 73: Ach, cóż to za pieniądze na tę robotę nazbierano, ale wzywam...

41 Tronu - ApP 73: honoru.

${ }^{42}$ Czują - w rpsie i ApP 73: czynią.

${ }^{43}$ Uwielbienie - ApP 73: ulubienie.
} 


\section{Stanisław}

Słuszna uwaga i najsprawiedliwsza, alboż to i Poniatowskiemu, który sobie niedościgłe założył panowania systema, a religiji katolickiej tyle zażywa, ile heroina ‘jego ${ }^{44}$ prawowiernej greckiej, ‘można długie obiecować uszczęśliwienie? ${ }^{45}$

\section{August II}

A na cóż czekać dalekich czasów? Jużci odebrał za swoje. Oto słyszałem niedawno od dzielnych bohatyrów konfederackich, że ‘od, ${ }^{46}$ kilkunastu drabów, co się po lasach i kępach około Warszawy tłukli złapany wśród miasta, ‘wpośród wojska, ${ }^{47}$ wyciągniony z karety, otrzepany mocno i pohańbiony został.

\section{August III}

Jestże to rzecz podobną: od Polaków? Król? Wśród Warszawy? Wpośród Moskwy? Od kilkunastu? A gdzież teraz on obraca się? To pewnie w Częstochowie?

\section{August II}

Nie miał on tam nabożeństwa.

\section{Stanisław}

Rzecz ciekawa, ale jeżeli go zawieziono, to tam nabożny być musi.

\section{August II ${ }^{48}$}

I owszem, nie godzi się tak sądzić o konfederatach, aby mieli tak z królem jakimżekolwiek postępować.

\section{Stanisław}

Ale kiedy go oni za króla nie uznają?

\section{August II}

To przynajmniej za stolnika litewskiego, i tego by tak szarzać ${ }^{49}$ nie dopuścili.

\section{Stanisław}

Żal nie ma uwagi, wszelkie prawa pękają, kiedy komu do żywego ${ }^{50}$ złość dopiecze.

\section{August II}

Jakożkolwiek bądź, Generalność tego nie dysponowała, dosyć miała na manifestach i ogłoszeniu interregnum. Do tej obrzydliwej rezolucyi jak żywo nie postą-

\footnotetext{
${ }^{44}$ Jego - brak w rpsie; uzup. za ApP 73.

${ }^{45}$ Można długie obiecować uszczęśliwienie? - w rpsie: uszczęśliwion długo będzie?; popr. za ApP 73.

${ }^{46}$ Od - brak w rpsie i ApP 73.

${ }^{47}$ Wpośród wojska - brak w rpsie; uzup. za ApP 73.

${ }^{46}$ W rpsie: $3 c i$.

${ }^{49}$ Szarzać - ApP 73: szanować.

${ }^{50}$ Do żywego - brak w ApP 73.
} 
piła,która paść nie może na tylu ‘tak ${ }^{51}$ godnych zebranych ludzi. Hultaje to tylko, zbiegli od komend, rozumiejąc, że się przypodchlebią swoim komendantom, taki sobie fajerwerk wyprawili. Ale co rzecz podziwienia jest godna, jeden z nich króla przyprowadził, a co większa komendant, ukradłszy go komendzie swojej, człowiek podły, bo przed rokiem $w$ Warszawie ${ }^{52}$ rangę lokaja noszący, chłop rodowity Kuźma zwany, a teraz Kosiński. Więc co uczyniono? Oto tę zbójecką sprawę pod imię wielkiego Pułaskiego podciągnięto, ażeby ją oszlachcić i okształcić.

\section{Stanisław}

Dlaboga! Romans jakiś do wierzenia niepodobny powiadasz, Auguście, albo coś prawdziwszego mając nam oznajmić, te alegoryje i misterne kombinujesz wyrażenia.

\section{August II}

Sumiennie powiadam, że tak jest w samej rzeczy, już mamy autentyczne o tym z tamtego świata świadectwa.

\section{August III}

Jeżeli z Warszawy, to ja ‘j,53 tym nie wierzę, bo tam i Ewangeliją nawet fałszują, $\mathrm{a}^{54}$ biskupi nauki swoje, które być powinny nienaganne zdrowe, nieinteresowane, w podchlebstwa i podłości przemienili; cóż za dziw, jeżeli i to zmyślili. Jest tam minister, najsławniejszy szalwierz między nimi, Młodziejowski, który jak Piłat w Credo wkręciwszy się w senat i ministeryjum, co większa, kiedy pieczęć wyższą porzucił sumienny świecki człowiek, on ją wymodlił i wyżebrał u kochanka swego Poniatowskiego, do którego teraz strzeliste akty miłości czynić każe pod eksḱkmunikami, ale mu się apostolstwo nie udaje; czyliż ten nie miał tyle głowy, żeby króla wyprawił, a udał i rozsiał ${ }^{55}$ po świecie, że go zabrano? Wszakże on, powiadają, że per omnes casus et genera szalbierstwa deklinuje i mógłby wielkie tomy składać z swojego machijawelstwa.

\section{August II}

'Sumiennie powiedasz, że tak jest w samej rzeczy. ${ }^{56} \mathrm{Kraczą} \mathrm{też} \mathrm{teraz} \mathrm{wszyscy}$ na niego o procesa, jakich jeszcze żaden nie wydał ${ }^{57}$ biskup, w których dla miłości jedynie swego pana i sakramenta obrzydził, i duchowieństwo podał na wzgardę, i naród cały szkaradnie opisał, sam tylko sobie przyznając gabinetową mądrość. I trzeba wiedzieć, że ten liziobrazek, zmyślony Aaron, szumny kanclerzyk najwięcej królowi szkodzi.

\footnotetext{
51 Tak - brak w rpsie; uzup. za ApP 73.

${ }^{52}$ W Warszawie - brak w ApP 73.

53 I - brak w rpsie; uzup. za ApP 73.

${ }^{54}$ A - w rpsie: i; popr. za ApP 73.

${ }_{55}$ Rozsiał - ApP 73: rozpisał.

${ }^{56}$ Sumiennie powiedasz... - brak w rpsie; uzup. za ApP 73.

${ }^{57}$ Nie wydat - ApP 73: nie wydawat.
} 


\section{August III}

Ej, czy tylko nie on tej historyi jest autorem?

\section{August II}

Jakże to być może, kiedy Poniatowski jest w Warszawie, obity i zraniony, i siedzi wraz w jednymże zamku z swoim dyrektorem, któregom wam opisał, Kuźmą, co jak Herostrat po spaleniu kościoła efezyjskiego wnidzie w kroniki.

\section{August III}

O Boże cudowny, cóż to ja słyszę! Widzę w niezamierzonych Boga wyrokach tę iszczącą 58) się prawdę, którą Chrystus ogłosił: Jaką miarą mierzycie, taką wam odmierzone będzie.

\section{Stanisław}

Z tobą by tego nikt nie uczynił, trzeba tylko Poniatowskiego na króla, aby tak był traktowany. Tyś był wspaniały, wielce cierpliwy, rozsądny, swój majestat i honor wielce poważający, tak dalece, że ledwie nie jako bożka Polacy cię szanowali. A chociaż Czartoryscy hardzi i zuchwali moskiewską wsparci łaską zamyślali o twojej detronizacyi, przecież i ci, chociaż najniecnotliwsi obywatele, więcej ważący ‘sobie, ${ }^{59}$ sobola moskiewskiego aniżeli wiarę i wolność, i wszystkich ziomków swoich, przecież ${ }^{60}$ blaskiem majestatu ${ }^{61}$ przerażeni, przy obecności twojej w Polszcze bąknąć nie śmieli. Dopiero kiedyś ostatni raz wyjachał do Saksoniji, roić się im poczęły fanatazyje i dawno suszone drewka, to jest siestrzeńca swego przez gwatt moskiewski i najazd na tronie osadzenie ${ }^{62}$. Ale o podobnym znieważaniu twoim nikt zapewne nie pomyślał.

\section{August III}

Ja tylko to mówię w szczególności, że ten junaczek swywolny, Ciołek, po wszystkich kątach, kompanijach mnie znieważał, imieniem i honorem moim niegodziwie szafował, w Moskwie mnie i syna mego Karola oczernit, hukami i hałasami poselską napełniał izbę, na wolność uciśnioną żalił się, którą on sam zgubił. Skarżył mnie o wprowadzone zagraniczne bronie, pod którymi sejmować było nie można, a ta była robota wszystka wujaszków jego.

\section{Stanisław}

Ma też ${ }^{63}$ teraz za swoje.

\section{August II}

Pożal się Boże tak wujów, jako też i siestrzeńca, zdaliby się zapewne do lepszych robót, wspierających się na sumnieniu, cnocie i sprawiedliwości.

\footnotetext{
${ }^{58}$ Iszczącą się - ApP 73: i szerzącą się.

${ }^{59}$ Sobie - brak w rpsie; uzup. za ApP 73.

${ }^{60}$ Przeciez - brak w ApP 73.

${ }_{61}$ Majestatu - ApP 73: majestatu twego.

62 I dawno suszone drewka... - ApP 73: aby siestrzeńca swego na tronie osadzili.

${ }^{63}$ Też - ApP 73: ten.
} 


\section{August III}

Skoro z religiji jarzma sumnienie wyprzęże się, za nic tam poczciwość i sprawiedliwość.

\section{August II}

A skądże wiesz ${ }^{64}$, że on jest bez religiji?

\section{August III}

Jeszcze za panowania mego, gdy z Angliji powrócił, chwalił się przed kobietkami, które dziś najsławniejszymi są w Warszawie kobietkami i w niezbożności rej prowadzą ${ }^{65}$, że nie umrze, aż z Polski Angliją zrobioną zobaczy. Otóż teraz przez gwatt dorwawszy się tronu, czyni w Polszcze Angliją. Pięknie i wiarę, i prawa, i swobody, i równych sobie niedawno obywatelów oanglizował. Poucinał i sprawiedliwości, i majątkom wszystkich ogony, i wiarę przez samo wprowadzenie wolności sumnienia chciał po angielsku zredukować66.

\section{Stanisław}

Święte i sprawiedliwe myśli twoje, Auguście; ta zapewne angielska jego gorliwość, ten stoicyzm ich szalony, który napuszył serce jego ${ }^{67}$, stał się ruiną razem i Rzeczypospolitej, i poczciwości jego. Boję się, żeby i koniec życia nie był po angielsku.

\section{August III}

To prawda, że tak się trafia po angielsku żyjącym. Pewniejszy jest dobrej śmierci, kto żyje po anielsku.

\section{August II}

Wszyscy się tedy królowie na jedno zgadzamy, że król zelżony nie wart pożałowania, kiedy sława publiczna o nim głosi, iż spiknąwszy się z nieprzyjaciółmi narodu chciał koniecznie zgubić naród, któremu poprzysiągł solennie być ojcem, stał $<m u{ }^{68}$ się niezbożnym ojczymem, a beśpieczeństwo wierze, swobodom i wolności zamienił w niezbożność, niewolą i okrucieństwo.

\section{Stanisław}

A kiedy też on $<z$ ' ${ }^{69}$ Moskwą się złoży i na nię wszystko zwali?

\section{August II}

To było królem nie podejmować się z takimi kondycyjami zostawać.

\footnotetext{
${ }^{54}$ A skądże wiesz - ApP 73: A skądże to ta wiadomość...

${ }^{65}$ Kobietkami i w niezbożności... - brak w ApP 73.

${ }_{66}$ I wiare przez samo wprowadzenie... - brak w ApP 73.

67 Serce jego - ApP 73: serca.

${ }^{68} \mathrm{Mu}$ - brak w rpsie; uzup. za ApP 73.

${ }^{69} \mathrm{Z}$ - brak $w$ rpsie: i ApP 73.
} 


\section{Stanisław}

A kiedy powie, że inaczej myślał, to jest dufając mężnym Polakom chciał użyć swego wyniesienia na ich szczęście, ale oni sami $w$ tę się burdę ${ }^{70}$ wprawili?

\section{August III}

Niechże się broni z Bogiem, niech panuje, niech znowu naród wprowadza w inszą łapkę. Nie rozumiej, Stanisławie, abym ja na niego był okrutnym, ja tylko nad Polską kochaną ubolewam.

\section{Stanisław}

Wiem o tym bardzo dobrze, i nie próbując się, ale sam dając sobie projekt do odpowiedzi tak dworuję. Służyć pewnie na obronę jego już nic nie może, bo kiedy waleczny naród nie przyjął dotąd jarzma i nie przyjmuje bez niego i adherentów jego, a cóż by dopiero było, żeby razem w jednomyślności był z nim spokojny? Ja najlepszym świadkiem jestem, bom dobrze biegły w polskich rzeczach, były klęski i po wielokroć razy nieszczęśliwy stan Rzeczypospolitej Polskiej, ale żadnego jeszcze nie było podobnego. Stanąć może wam wszystkim na oczach okropność Polski za panowania Jana Kazimierza, kiedy król szwedzki Gustaw prowadził wojska w granice polskie, opanował Wielkopolskę i Kraków, wszędzie obrzydliwe spustoszenia i okrucieństwa zostawując ślady, a to wtenczas, kiedy Rakoczy z Węgrzynami, Chmielnicki z kozactwem i Tatarami, nie bez pomocy moskiewskiej $w$ Litwie grasującej, na sztuki rozrywali Polskę ${ }^{71}$. Ale chociaż tyle skupiło się nieszczęśliwości razem na zniszczenie tego narodu, przecież że to wszystko działo się otwarcie, po nieprzyjacielsku, prędzej się uspokoić mogło.

\section{August II}

Prawda, gwałtowny ogień prędzej zalać można, aniżeli ten, który się skrycie zakradnie, i wszystkie bez postrzeżenia żadnego powoli ogarnąwszy zakątki nie pierwej wybuchnie, aż dom cały w popiołach z fundamentu osiędzie.

\section{Stanisław}

Słodziło to Polakom wszystkie przykrości i nieszczęścia, kiedy król z nimi razem trzymał, razem ponosił tę nawałnicę, ani się łączył z żadnym mocniejszym narodu nieprzyjacielem, ale oczekiwał $w$ cierpliwości albo $z$ narodem powstać do szczęścia dawnego chwały, albo z nim ginącym razem zginąć. A któż z Polaków mógł bez kryminału natenczas porzucić Ojczyznę, kiedy widział króla w pierwszych szykach na nieprzyjaciół stawającego ${ }^{72}$, kiedy widział, jako on pod Zbarażem Firlejowi oblężonemu na sukurs przychodząc, sam się narażał na śmierć za swój poddany lud, kiedy sam $z$ rany wyciągał skaleczonych cnotliwych Polaków strzały i ranionym starostwa rozdawał, kiedy i głosem, i wszelkimi, na które się mógł

\footnotetext{
${ }^{70}$ Burdę - ApP 73: burzę.

${ }^{71}$ Nie bez pomocy - ApP 73 Moskwa zaś w Litwie grasując na sztuki kraj rozrywali.

72 Stawającego - w rpsie: stojącego; popr. za ApP 73.
} 
zdobyć, siłami i łożeniem wszystkiego, co miał, ten kochający Ojczyznę król ${ }^{73} \mathrm{w}$ dopuszczonych na nię od Boga nieszczęśliwościach wpośród rozpaczy nie odstępował jej szczerze, a na ostatek uchylając kark swój sprawiedliwym Boga wyrokom i jako wielki katolik swojemu panowaniu te nieszczęścia przypisując, uspokoiwszy Rzeczpospolitę i z nieprzyjaciół oswobodziwszy, dobrowolnie tron abdykował. O cudowny postępek! o prawdziwa miłości, godna serca monarchy, ku swemu narodowi! To mi to Jonasz prawdziwy, który wolał sam utonąć, byle wielu innych ocalało. To mi to Decyjusz, który sam wolał w rozwalinach przepadnąć, być pogrążonym, aby stała kochana ojczyzna i żyli ziomkowie. Niegodzien mu ten szpady podać ${ }^{74}$ który, aby tylko panował, woli się bezwstydnie przedać nieprzyjaciołom, patrząc na ich ręce i dependując od ich ukazów ${ }^{75}$, aby swoich ziomków i rodaków zgubił.

\section{August $\ \|>^{76}$}

Cóż to za myśl szalona! On rozumie, że zawsze Moskwa pod jego wolą chodzić będzie i wodzić go na paskach jako piastunka jego honoru i szczęścia. Co to za prewencyja wrzekomo przy rozumie siedzieć w Warszawie między kobietkami po Sardanapalowsku, w rozkoszy opływać przy azardach i niewinnej śmierci Moskalów, i wyglądać tylko, jako myszy z pudła, rychłoli wszyscy wyginą jego ziomkowie. Czytamy w historyjach, że maleńkich królów na plac wynoszono podczas fatalnych batalij, gdzie szło o ucalenie narodu, i zaraz na samo widzenie pana swojego zwiększona ochota, serca zapalone wpośród nachylającej się już fortuny odzyskiwały swój honor i zwycięstwo. Ale takich szalonych nie czytamy historyj, żeby król przez fortele kłamliwe wprowadziwszy wśród narodu nieprzyjaciela, związał się z kliką najpodlejszych adherentów, bez czci, bez honoru, bez sumnienia, bez bojaźni Boga, bez miłości Ojczyzny, bez ludzkości i litości nad nędzą współbraci swoich, zamknął się w jednej dziurze, zdał los szczęścia swojego na nieprzyjaciół i czeka szczęśliwego natenczas panowania, kiedy nad nim panować nie będzie ${ }^{77}$.

\section{August III}

W głowę <mi ${ }^{78}$ to wleźć nie może, bo o podobnej nigdzie nie czytało się rewolucyi ani się o niej nie słyszało.

\section{Stanisław}

A przecież ten człowiek ma renomę, że jest mądry.

\section{August III}

Mądrość bez serca poczciwego jest to szalonemu miecz podany na zgubę in-

\footnotetext{
${ }^{73}$ Kochający Ojczyznę król - ApP 73: kochany król.

${ }_{74}$ Niegodzien mu ten szpady podać - ApP 73: Niegodzien tej chwały.

75 Patrząc na ich ręce... - brak w ApP 73.

${ }^{76} \mathrm{~W}$ rpsie: 3ci; popr. za ApP 73.

77 I wodzić go na paskach... - ... panować nie będzie - brak w ApP 73.

${ }^{78} \mathrm{Mi}$ - brak w rpsie; uzup. za ApP 73.
} 
nych i samego siebie. Pająk sieci wije na muchy, a potym częstokroć sam w nich uwięźnie i życie marnie skończy ${ }^{79}$.

\section{Stanisław}

Cóż, kiedy to poszło za prawo u panujących wielu, iż nie mają inszych prawideł swojej polityki, tylko obłudę i same cygaństwa ${ }^{80}$.

\section{August II}

Ale pytam się, czy to tak być powinno?

\section{August III}

Ale czy tak Bóg rozkazuje?

\section{Stanisław}

Kiedy śpią teraz posłańcy boscy i listów nam od Pana Boga nie czytają, ale bajki, fałsze i pochlebstwa. I nie dziw, wypisali się w domach i wygadali z prawdą Klemensowie, Cypryjanowie, Augustynowie, to teraźniejszym biskupom nie zostało się nic, tylko ukryte sprężyny gabinetowe. Pisze Młodziejowski gorliwe satyry, miota pioruny na poczciwych obywatelów, a sam jadem tchnie skrytym przeciwko Bogu, wierze i Ojczyźnie.

\section{August III \\ Kiedy mu dobrze płacą.}

\section{Stanisław}

Ale zapłacą potym lepiej w piekle.

\section{August III}

Otóż to lepiej tak mówić, Stanisławie, aniżeli na jezuitów rzucać potwarze, jakoś przedtym mówiąc ze mną czynił.

\section{Stanisław}

Nie bój się o nich; dlaboga, Auguście, właśnie zdaje się, jakobyś był generałem jezuickim, tak się szarpiesz za nimi. Większać zapewne, większa wina w biskupach. Ci są nauczyciele samych pasterzów, ci są na czele w senacie, mając pierwszeństwo miejsca i głosu z woli przodków, opiekunów wiary i wolności, a przecież gdy te giną, oni śpią na to bardzo dobrze.

${ }^{79}$ Mądrość bez serca... - ApP 73: Mądrość bez gruntu poczciwości charakteru nic nie jest, i ta mądrość głupstwem nazwana być powinna i szaloną obłudą.

${ }^{80}$ Odtąd w ApP 73: (Stanisław)Tegoż samego naśladuje senat i ministrowie, wszakże regis ad exemplum totus componitur orbis. Już i biskupi takowym napojeni jadem, wiem, że czytałeś, Auguście, gorliwe księdza Młodziejowskiego pismo, a bardziej satyry piorunujące na poczciwych obywatelów, wiary i wolności przykładnych obrońców. 


\section{August II}

Co oni dbać mają o wiarę i ojczyznę? zubożały bardzo teraz te dwie panie i nie mają czym płacić.

\section{Stanisław}

Ale tak być powinno, mają intraty bardzo wspaniałe i przywileje nieskończone, aby czuli, ujmowali się za te obydwie powierzone sobie sieroty.

\section{August II}

Wiem ja dobrze prawo polskie, iż prymas, biskup kujawski, krakowski i inni mogą zażyć mocy upominania króla, gdyby publicznie z pogorszeniem błądził, i zdobywać się na gorliwość Jana: Non licet, non licet tibi, rex.

August III: Darmo, darmo, mało mamy takich apostołów, jeden tylko Młodziejowski, ten jeden tylko gorliwy biskup, woła on często: non licet, non licet.

Stanisław: Cóż po tym, kiedy tych słów nie używa przeciwk: Herodowi, ale za Herodem; wlazł w senat i ministeryjum jak kozioł w kapustę, przez swoje pisma szkaluje naród, księży na sztych wydaje, sakramen ‘t’ spowiedzi czyni obrzydliwym, przez wnętrzności Pana Jezusa zaklina, aby kochać króla, a króla takiego, co też same wnętrzności i Ojczyzny swojej szarpie, a czyni to dlatego, aby jemu samemu dobrze się działo.

August III: Nie rozumiem, żeby ta gorliwość tego biskupa taki cel miała, jak mi namieniasz, Stanistawie.

Stanisław: Ten, a nie inszy, tylko aby się uszczęśliwił, a obywatelów gorliwych, zamysłom króla sprzeciwiających się, wszystkich jak najprędzej gruzem fatalności narodowych widział przywalonych.

August II: Nie mówię o Młodziejowskim, bo ten szczupłej familiji, nie ma czego żałować, ale prymas, ale insi biskupi, ale insi senatorowie, świeccy familijanci?

Stanisław: Prawda, jest to arcydzielna myśl, ale cóż po tym, kiedy nikt im wyperswadować nie może, grzech ich przywiódł do tej rozpaczy, że za niego żałować nie mogą.

August III: Nie mogą, bo nie chcą, bo się spodziewają ubóstwić i kolosami wsławić, gdy swego dokażą, a gdy na tym staną stopniu, myślą, że zawsze wszystko będzie po ich woli, wszakże

Kruk kruka nie podziobie ani też wilk wilka

Pokąsa, prędzej zginie nędznych owiec kilka,

Gdy się zmówią pożercy, okrutne szkodniki.

Będzie pusta obora; woły i koniki,

Co pracują i krwawią, na chleb robią doma,

Próżniakom pastwa będzie, zje ich złość łakoma.

August II: Ale od tych wierszyków trzeba by przystąpić ad seria.

Stanisław: Kiedy ad seria, otom ja prorokiem, ale nie z kalendarza: Sas znowu będzie królem polskim, a tak

Będzie za Sasa w Polszcze i mleko, i wełna,

Dostatki, handle, zbiory, i obfitość zupełna.

August 11: To już swoje znowu zaczynasz?

Stanisław: Bo ja stały zawsze przy swoim mniemaniu i nigdy się nie odmienię. Niechaj warszawscy politycy smażą się nad projektami za Polakiem królem, ja jedno zawsze mówię, że źle dla Polaków mieć króla Polaka. Ale widzę, że ku nam Sobieski idzie. Wiem, że i on, chociaż także rozmaity Polak, jednego ze mną będzie zdania. Pamiętajcie przebóg, żebyście mię nie wydali, iżem projekta jego szumne jak na dłoni wam objawit.

August III: Przyrzekamy, że się sprawiemy dobrze, ale i ty porzuć Sasów i pokaż się obojętnym, dosyć nam na twoim szczyrym sercu i życzeniu.

August II: Wynidźmy ku niemu, bo już nas jest blisko. 


\section{Stanisław}

Bo też nie ma teraz w Polszcze biskupa żadnego Jana, był biskup krakowski i kijowski, to już za to non licet gorliwe sobole na Syberyi strzelają. Prymas Epikur, chwała Bogu, że ma Emkiniją z córką, nie suszy sobie głowy o wiarę i wolność. A kiedy biskup krakowski pasował się o pokrzywdzenie tych sierot i na wszystko odważał się, powiadając, iż chyba na kamieniu, który głowę jego przywali. pierwszy dysydentów stanie się kościół, natenczas prymasowi, dysydentów opiekunowi, dla miłości Emkini gdy pięćset tysięcy złotych polskich ze skarbu koronnego przydać rozkazano, mój prymas myczkę z głowy zdarłszy co żywo na paluszkach do tronu, asekurując sekretnie, że gut, gut, będzie się miała z pyszna wiara. Kújawski ma swoje dzierżawy, arendy, browary i pensyją moskiewską, a cóz mu potym za wiarą być męczennikiem? Płocki zegarki naprawia i chędoży, a konfederatów przeklina, chociaż mu Moskale stare wino wypijają i komisarują dobrze w dobrach, nie dba o to, przynajmniej, że między zegarmistrzami w Warszawie siedzieć może.

\section{August III}

Ale Młodziejowski to gorliwy biskup, to Jan odważny, pisze i woła: non licet, non licet.

\section{Stanisław}

Cóż to po tym, kiedy tych słów nie używa do Heroda, ale za Herodem, wlazł w senat i ministeryjum jak kozioł w kapustę, trzeszczy, szumi, szkaluje naród, księży na sztych wydaje, sakrament spowiedzi, o który i tak świeccy nie dbają, czyri obrzydliwym. Przez wnętrzności Pana Jezusa zaklina, aby nie kochać ojczyzny, tylko króla, a tymczasem też same wnętrzności Chrystusa szarpie, wziąwszy Rebau od lutrów i znaczne do Moskwy dona charitatis. Ogarnął oprócz tego poznańskie biskupstwo z kanclerstwem, czego insi, godniejsi, świętsi i poczciwsi mieć nie mogli. Bniński na przykład, ów sławny biskup poznański, nie miał opactwa żadnego, nie miał kanclerstwa intratnego, nie miał pensyi moskiewskiej ani pobożnych składek od lutrów, ani jałmużn od bogatych malowanych wdówek, a żadną miarą nie dopuścił, resolwując się na wszystko, aryjanom i innym heretykom wstępu do senatu i urzędów ani do swojej diecezyi, a teraz pan Młodziejowski na to pozwala, byleby mu się dobrze działo.

\section{August II}

Jest to piękna bajeczka o wilku, który widząc się u wszystkich być w obrzydzeniu i nienawiści dlatego, że na mięso był łakomy, postanowił być zawsze suchotami. Pości tedy, wędzi się moje wilczysko, czołga się, polizuje trawki, żywi się korzonkami, ktćre go nie nasycały, i aby się przy swoich ślubach utrzymał, woli ná siłach upaść i zginąć. Tymczasem $w$ tej pobożności i mortyfikacyi zostając ścisłej, zbiega raz z jednego pagórka, aż widzi z daleka, że pasterze drą ze skóry tłustych baranów, na rożny zatykają i rąbią w sztuki jeszcze drżące mięso do kotła. „A mnie skąd to szaleństwo ogarnęło? - w tym razie krzyknie - a cóż to za przewró- 
cenie natury; wilk, którego powołanie drzeć i mordować, pości, wędzi się, a pasterze, których powołanie strzec trzody, pilnować, pielęgnować, na barkach nosić, zabijają okrutnie i mięsa jako wilcy obżerają się. Nie tak odtąd będzie, już kwita z świątobliwości i umartwienia. Przykłady te i zgorszenia pasterzów jeszcze mnie okrutniejszym i łakomszym od dziś dnia uczynią wilkiem". Wypadł tedy jako zbójca, rzucił się na owieczki, pomordował szztuk kilka i dalej jak przedtym do swego lasu. Nie dziw tedy, że król z adherentami podłymi i łakomymi, z natury i ułożenia się będąc wilkami, tak są łakomi na skórę i mięso niewinnych owieczek, kiedy księży, pasterzów, napominaczów, arcywilka najstarszego przykłady są mu do okrucieństwa powodem. Mają oni kij w ręce, to jest ekskomuniki, kary kościelne, oskarżenie w senacie i na sejmie na innych szkodnych pomniejszych wilków, mają na nich doły i żelaza w trybunale sub titulo Arianismi in foro mixti iudicii, łapaliby i sprzątali gładko tych wilczków, ale kiedy sami wolą być wilkami niż pasterzami, toteż i to prawda być musi:

Kruk kruka nie podziobie ani też wilk wilka

Pokąsa. Prędzej zginie nędznych owiec kilka,

Gdy się zmówią pożercy, okrutne szkodniki,

Będzie pusta obora; woły i koniki,

Co pracują i krwawo na chleb robią doma,

Próżniaków pastwą będą, gdy chce złość łakoma.

\section{August III}

Ale od bajek i wierszyków trzeba by nam też przystąpić ad seria.

\section{Stanisław}

Otóż ja prorokiem, ale nie z kalendarza, nie z inspektów i kwadratur niebieskich: Sas będzie znowu królem w Polszcze, wilków tych wypoluje i wyszasta. Lepiej będzie dla niewinnej trzódki:

Będzie za Sasa króla i mleko, i wełna,

Dostatki, handle, zbiory, obfitość zupełna.

\section{August III}

To już znowu swoje zaczynasz?

\section{Stanisław}

Bo ja stały zawsze przy swoim mniemaniu i nigdy się nie odmienię. Niechaj jak w alembikach smażą dzisiejsi warszawscy politycy w swoich głowach racyje i projekta za»Polakiem, ja jedno zawsze mówię, że źle dla Polaków mieć króla Polaka... Ale widzę, że ku nam Sobieski idzie; wiem, że i on, chociaż rodowity Polak, zgodzi się ze mną. Pamiętajcie przebóg, żebyście mnie nie wydali, iżem go wyegzenterował i projekta jego szumne jak na dłoni wam objawił. 


\section{August III}

Przyrzekamy, że się sprawiemy dobrze, ale i ty porzuć Sasów, pokaż się obojętnym, dosyć nam na twoim szczerym sercu.

\section{August II}

Pódźmy ku niemu, bo już nas jest blisko. 